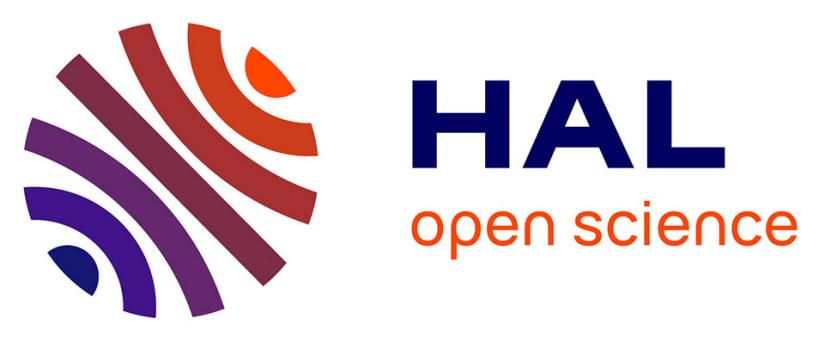

\title{
The killer shrimp, Dikerogammarus villosus, invading European Alpine lakes: a single main source but independent founder events with an overall loss of genetic diversity.
}

Tomasz Rewicz, Remi Wattier, Thierry Rigaud, Michal Grabowski, Tomasz

Mamos, Karolina Bącela-Spychalska

\section{To cite this version:}

Tomasz Rewicz, Remi Wattier, Thierry Rigaud, Michal Grabowski, Tomasz Mamos, et al.. The killer shrimp, Dikerogammarus villosus, invading European Alpine lakes: a single main source but independent founder events with an overall loss of genetic diversity.. Freshwater Biology, 2017, 62 (6), pp.1036-1051. 10.1111/fwb.12923 . hal-01525665

\section{HAL Id: hal-01525665 \\ https://hal.science/hal-01525665}

Submitted on 28 Dec 2021

HAL is a multi-disciplinary open access archive for the deposit and dissemination of scientific research documents, whether they are published or not. The documents may come from teaching and research institutions in France or abroad, or from public or private research centers.
L'archive ouverte pluridisciplinaire HAL, est destinée au dépôt et à la diffusion de documents scientifiques de niveau recherche, publiés ou non, émanant des établissements d'enseignement et de recherche français ou étrangers, des laboratoires publics ou privés. 
1

2

3

4

5

6

7

8

9

10

11

12

13

14

15

16

17

18

19

20

21

22

23

24

25

26

27

28

29

30

31

32

1 The killer shrimp Dikerogammarus villosus invading the Alpine Lakes: A single main source

2 but independent founder events with an overall loss of genetic diversity

3

4 Tomasz Rewicz ${ }^{1,2 *}$, Remi Wattier ${ }^{3}$, Thierry Rigaud ${ }^{3}$, Michał Grabowski ${ }^{2}$, Tomasz Mamos ${ }^{2}$, 5 Karolina Bącela-Spychalska ${ }^{2}$

6

$7{ }^{1}$ University of Lodz, Laboratory of Microscopic Imaging and Specialized Biological Techniques, 8 Banacha 12/16, Łódź 90-237, Poland

$9 \quad{ }^{2}$ University of Lodz, Department of Invertebrate Zoology and Hydrobiology, Banacha 12/16, Łódź $1090-237$, Poland

$11{ }^{3}$ Université de Bourgogne Franche-Comté, Laboratoire Biogéosciences, Equipe Ecologie

12 Evolutive, UMR CNRS 6282, 21000 Dijon, France

13

$14 *$ corresponding author

15 Running title: Origin and introduction sources of Dikerogammarus villosus in Alpine Lakes

16 Key words: invasive species, dispersal, overland transport, demography, Ponto-Caspian 


\section{Abstract}

1. The effects of biological invasions are generally more detrimental in isolated ecosystems than in the interconnected ones and freshwater lakes appear to be particularly fragile. The alien freshwater amphipod Dikerogammarus villosus, also known as the killer shrimp, is recognized as a major conservation problem. It has colonized most of the European main inland water bodies, including at least twelve lakes in the Alps - an area of high conservational priority and, at the same time, heavily affected by anthropogenic changes. Particularly, overland translocations of boats among touristic centres may have contributed to colonization of the Alpine Lakes.

2. We aimed to answer the following questions: Which of the two genetically differentiated populations invading continental lowland Europe has contributed to colonisation of the Alpine Lakes? Is it possible to detect independent founder events in different regions of the Alps and/or secondary spread among Alpine Lakes? Have the lacustrine populations suffered any reduction of genetic variation during colonization? Twelve populations from the Alpine Lakes were genotyped for a portion of mtDNA (COI and 16S) and for seven nuclear microsatellite loci. A wide range of methods was used to analyse the data, including haplotype network, Bayesian clustering and demography tests.

3. Our results show that the lowland western route (Danube-Rhine waterway) of the killer shrimp invasion was the source for introduction to the Alpine Lakes. Unlike invasive populations in the main lowland rivers, most of the Alpine populations suffered bottleneck and had significantly lower genetic diversity compared to their source population along the western route. We found clear patterns of genetic structure, revealing multiple independent lake colonisations followed by secondary spread between lakes. An overland transport of $D$. villosus with touristic boats is probably the major spreading vector to and among Alpine Lakes. Implementing safety programs such as the 'check, clean, and dry' procedures may stop or slow down spreading of Dikerogammarus villosus among the Alpine Lakes, and prevent additional long distance transport. 
48

49

50

51

52

53

54

55

56

57

58

59

60

61

62

63

64

65

66

67

68

69

70

71

72

73

74

75

76

77

78

79

80

\section{Introduction}

Biological invasions are among the flagship symbols of globalization and a major threat to biodiversity at various scales (Simberloff et al., 2013). Fast and uncontrolled spread of terrestrial and aquatic alien species may cause irreversible changes in local ecosystems. Alien invaders compete for shelters (Kinzler \& Maier, 2006; van Kessel et al., 2011) and food (Dick \& Platvoet, 2000; Kakareko et al., 2013) with native biota, transmit new pathogens (Bącela-Spychalska et al., 2012; Peeler et al., 2011; Poulin et al., 2011) or even transform local habitats (Cuddington \& Hastings, 2004; Rodríguez et al., 2005; van Riel et al., 2006).

Probability of successful establishment of an invasive population is, to some extent, associated with propagule pressure that combines the propagule size (i.e. the number of founding individuals) with the frequency of introduction events (Lockwood, Cassey \& Blackburn, 2005; Von Holle \& Simberloff, 2005). Small propagule pressure may result in genetic founder effect often causing negative consequences to genetic diversity, such as allelic loss and/or inbreeding (Deredec \& Courchamp, 2007). Conversely, retention of genetic and phenotypic diversity associated with high propagule pressure may significantly increase further success of the founding population, especially if the new habitat is different from the source habitat (Dlugosch \& Parker, 2008; Roman \& Darling, 2007). Populations of invasive species characterised by high level of genetic diversity may be less vulnerable to enemies (predators or diseases) (Zhu et al., 2000) and respond faster and more efficiently to changing environmental conditions (Lavergne \& Molofsky, 2007). There are now evidences that bottlenecks in invasive populations are not as common as thought before (Genton, Shykoff \& Giraud, 2005; Kolbe et al., 2004; Rewicz et al., 2015a). High propagule pressure may originate either from massive single introduction or from multiple introductions from a single source (Forsman, 2014).

Inland waters are particularly vulnerable to biological invasions (Bij de Vaate et al., 2002; Funnell et al., 2009; Jażdżewski, 1980; Rewicz et al., 2015a; Ricciardi \& Rasmussen, 1998; Strayer, 2010). Various human activities favour the introduction or spread of alien species: (1) commercial shipping, through biofouling and ballast waters (Drake \& Lodge, 2004), (2) recreational activities such as angling, boating, canoeing, diving, mainly through biofouling (Anderson et al., 2014; Bącela-Spychalska et al., 2013) and (3) intentional releases (Funnell et al., 2009; Barbashova, Malavin \& Kurashov, 2013). Introductions may result from overseas transport (Muirhead et al., 2015), from transport along waterways, notably through canals that connect previously isolated drainages (Bij de Vaate et al., 2002; Jażdżewski, 1980), or even from overland transport (Anderson et al., 2014; Bącela-Spychalska et al., 2013). 
81 Inland lakes may be prone to invasion to a various extent. On one hand, some lakes, e.g. the 82 Laurentian Great Lakes (LGL), are characterized by high commercial shipping allowing massive 83 and recurrent introductions (Adebayo et al., 2014; Holeck et al., 2004). On the other hand, many 84 lakes, especially those in the European Alps, may be at lower risk of alien species introduction due 85

86 87 88 89 90 91 92 93 94 95 to their relative isolation from the main waterways. However, in many areas, lakes are geographically clustered. As a result, even if long distance introductions into a given lake are expected to be rare, once a given lake is colonized, the probability of secondary introduction to the neighbouring lakes is high. Even if such lakes are not connected by waterways, overland transport associated with recreational activities - such as angling, boating, canoeing or diving - creates such connexions ( Bącela-Spychalska, 2016; Bącela-Spychalska et al., 2013; Johnson, Bossenbroek \& Kraft, 2006). For example, small lakes in the vicinity of the LGL were shown to be susceptible to secondary spread of alien aquatic species by such overland transportation (Johnson, Bossenbroek \& Kraft, 2006; Johnson, Ricciardi \& Carlton, 2001; Kerfoot et al., 2011). Small propagule size and bottlenecks associated with reduced genetic variation are expected in populations newly developed in such isolated minor lakes.

The amphipod Dikerogammarus villosus (Sowinsky, 1894), aka the killer shrimp, is one of the most efficient invaders in aquatic ecosystems (DAISIE, 2009). Issued from the Ponto-Caspian area, where it lives in large rivers or deltas and limans, it has successfully colonized main lowland continental European waterways during the last thirty years. Large navigable waterways with intense commercial shipping traffic, connected through artificial channels, are recognized as primary colonization routes, often called "invasion highways", for the killer shrimp in lowland continental Europe (Bij de Vaate et al., 2002; Leuven et al., 2009; Rewicz et al., 2015a). Dikerogammarus villosus inhabits stony substrates and is often found within zebra mussel beds. Its feeding regime is scavenger/predatory at adult stage, while juveniles show a more diversified diet including algae (reviewed in Rewicz et al., 2014). Its high trophic level resulting from predatory behaviour (van Riel et al., 2006) as well as wide tolerance to temperature and conductivity fluctuations (Bruijs et al., 2001; Wijnhoven, van Riel \& van der Velde, 2003) combined with early sexual maturity and high fecundity (Grabowski, Bącela \& Konopacka, 2007a; Pöckl, 2007; Pöckl, 2009) are favourable life-history traits in the initial phases of invasion. The presence of $D$. villosus induces negative effects on local communities, such as an increase of direct predation pressure on other invertebrates and fish spawn (Buric et al., 2009; Platvoet et al., 2009; van der Velde et al., 2009), competition for shelters (MacNeil et al., 2011) and modification of entire food webs (van Riel et al., 2006). 
114

115

116

117

118

119

120

121

122

123

124

125

126

127

128

129

130

131

132

133

Phylogeography and population genetics of Dikerogammarus villosus in its native and invaded ranges was studied by Wattier et al. (2007) and Rewicz et al. (2015a). Native populations of the Dnieper and the Danube deltas are genetically differentiated and provide sources for, respectively, eastern and western invasion routes of $D$. villosus invasion in continental lowland Europe (Fig. 1a). The eastern route is limited to the rivers or canals in Ukraine and in eastern and central Poland. The western route covers the rest of the vast colonized area in continental Europe, including the Danube with its tributaries, Rhine River, natural and artificial watercourses in France, Netherlands, Germany and western Poland (Fig. 1a). Neither loss of genetic diversity nor genetic differentiation were observed between native and invaded areas, even along the entire, ca. $4500 \mathrm{~km}$ long, western route (Wattier et al., 2007; Rewicz et al., 2015a).

In addition to rivers and canals, at least twelve lakes at low altitudes in European Alps (here after called ''Alpine Lakes") have been invaded by D. villosus (Bącela-Spychalska et al., 2013 and references cited herein, Fig. 1b, Table 1). These lakes vary in size and intensity of tourist activities. The hydrological connections between the lakes and to the "invasion highways" are also variable (Leuven et al., 2009) (Fig. 1b, Table 1). The western invasion route partly encircles the Alps from the north and west and is directly connected to some Alpine Lakes, suggesting that the D. villosus populations in the Alpine Lakes may originate from this source. Yet, the connections are scattered, lowering the probability of a single massive introduction in this area. On the other side, a touristic boat traffic from distant locations is known to occur in Alpine Lakes. Some boats are transported overland from Northern and Central Europe, i.e. from countries along the eastern invasion route (de Ventura et al., 2016). Dikerogammarus villosus endures the overland transport: Martens \& Grabow (2008) reported that it can survive six days out of water within zebra mussels biofouling on a boat propeller. Bącela-Spychalska et al. (2013) showed that D. villosus can survive two days in between layers of scuba-diving suit. Such abilities may favour long-distance colonisation of the Alpine Lakes, where sailing and diving is a very common touristic activity. Therefore, presence of founder individuals from both the eastern and the western population of $D$. villosus are possible, opening the chance for independent founder events in different parts of the Alps. De Ventura et al. (2016) showed that boats are frequently transported overland between Swiss Alpine Lakes; some lakes (e.g. lakes Bienne, Murten and Neuchâtel) being additionally interconnected by small waterways. These features may result in secondary spread of $D$. villosus from lakes with already established populations.

The pattern of $D$. villosus invasion in Alpine Lakes is interesting to investigate because it may strongly influence the pattern of its genetic diversity. The killer shrimp populations maintained their genetic diversity along the highways of invasion (Rewicz et al., 2015a). Yet, we cannot reliably 
148 predict if this diversity has been maintained after their introduction in the Alpine Lakes. Predictions

149 are ranging from low diversity in isolated lakes, associated with single introduction and strong

150 bottleneck, to high diversity in lakes well connected to invasion highways and colonized long time

151 ago with individuals arriving each year. In addition, it cannot be excluded that genetic diversity

152 (and consequently the invasive capacity) can increase in result of admixture between introductions

153 from multiple and previously isolated sources (here, the western and the eastern route) (Lombaert et 154 al., 2011).

155 In this study, populations of Dikerogammarus villosus from the twelve colonized Alpine Lakes 156 were genotyped for mtDNA (COI, 16S) and seven polymorphic nuclear microsatellite loci.

157 Molecular markers are known to be powerful tools in tracking invasion patterns and dynamics

158 (Ficetola, Bonin \& Miaud, 2008). The markers used here were successfully applied in a large scale 159 study upon phylogeography and invasion dynamics of the killer shrimp in continental lowland 160 Europe (Rewicz et al., 2015a). By revealing the population genetic structure in Alpine Lakes and 161 comparing it to results of this previous study, we addressed the following questions: (1) Is the 162 western route the only source for the populations established in the Alpine Lakes? 2) Is it possible 163 to detect cases of independent founder events in different areas of the Alps and cases of secondary 164 spreading between neighbouring lakes? (3) Have Alpine lacustrine populations suffered from a 165 reduction of genetic variation?

\section{Materials and Methods}

\section{Sample collection and molecular marker data production}

169

170

171

172

173

174

175

176

177

178

179

Dikerogammarus villosus were collected from the littoral zone of twelve lakes in European Alps (Fig. 1b, Table 1) as described by Bącela-Spychalska et al. (2013) and conserved in 96\% EtOH directly after sampling. Total DNA was extracted from 415 individuals with a standard phenolchloroform method following Hillis, Moritz \& Mable, (1996). Air-dried DNA pellets were eluted in $100 \mu 1$ of TE buffer, $\mathrm{pH} 8.00$, stored at $4^{\circ} \mathrm{C}$ until amplification, and subsequently at $-20^{\circ} \mathrm{C}$ longterm storage. Two mtDNA markers were amplified to a random subset of the initial 415 individuals used for microsatellite analyses, for a total of 128 specimens: 16S ribosomal RNA (16S rRNA; ca. 320 bp fragment) with LR-J-GAM/LR-N-GAM primers (Müller, Schramm \& Seitz, 2002) and reaction conditions following Grabowski et al. (2012) and cytochrome oxydase subunit 1 gene (COI; ca. 670 bp fragment) with LCOI490/HCO2198 primers (Folmer et al., 1994) and reaction conditions following Hou, Fu \& Li (2007). Sequences were obtained with BigDye sequencing 
180 protocol (Applied Biosystems 3730xl) by Macrogen Inc., Korea. The obtained sequences were

181 edited, aligned and trimmed with CLUSTALW algorithm (Chenna et al., 2003) using BIOEDITC) 1827.2 .5 , leading to 128 sequences of $16 \mathrm{~S}(303 \mathrm{bp})$ and COI (654 bp) which were concatenated prior 183 analyses. Haplotypes were retrieved using DNASP v5 both for individual markers and for the 184 concatenated dataset (Librado \& Rozas, 2009). Haplotypes for individual markers are presented in 185 Table S1. One newly detected COI haplotype was deposited in GeneBank (KP814111). Other 186 haplotypes were already identified after Rewicz et al. (2015a).

187 Seven microsatellite loci (Msat) were used as nuclear co-dominant molecular markers: DikS, DikF 188 (Wattier et al., 2006), Dv11, Dv13, Dv17, Dv31, Dv33 (Rewicz et al., 2015b). Altogether 415 189 individuals were genotyped. The PCR conditions were described by Wattier et al. (2006) and by 190 Rewicz et al. (2015b). It is to be noticed that DikF is not amplifying in the eastern source/route 191 (Rewicz et al., 2015b). Microsatellite alleles were visualized in 6.5\% acrylamide, $25 \mathrm{~cm}$ long gels 192 on a LICOR $4200 \mathrm{~L}$ automated sequencer and scored by eye. Reference individuals were included 193 for inter-gel calibration. Absence of physical linkage disequilibrium was tested using the software 194 GENEPOP (Rousset, 2008) and absence of recurrent genotyping errors and their possible sources 195 e.g. short allele dominance (Wattier et al., 1998) was checked with the software MICRO-

196 CHECKER version 2.2.3. (van Oosterhout et al., 2004).

197 198 199 200 201 202 203 204 205 206 207 208

209 210
To compare the present data to the large-scale picture of $D$. villosus phylogeography in continental lowland Europe, 274 mtDNA sequences and microsatellite genotypes of 723 individuals analysed by Rewicz et al. (2015a) were also used in this paper.

Assessing the spatial distribution of diversity

To visualize molecular divergence of mtDNA haplotypes and their spatial distribution, a Minimum Spanning Network was generated using ARLEQUIN 3.5.1.2 (Excoffier \& Lischer, 2010). Pairwise differentiation in haplotype and alleles frequencies was determined by two $F_{\mathrm{ST}}$ estimators: $\Theta_{\mathrm{ST}}$ with Tamura-Nei distance for mtDNA (Tamura \& Nei, 1993) and $\Theta$ for microsatellites (Weir \& Cockerham, 1984), both implemented in ARLEQUIN 3.5.1.2 (Excoffier \& Lischer, 2010), statistical significance was measured using 10000 permutations.

The population genetic structure was also analysed for Msat using individual-based Bayesian clustering method implemented in STRUCTURE 2.3.4 (Pritchard, Stephens \& Donnelly, 2000). A first simulation was performed on a large dataset composed of populations from the Alpine Lakes, western route, eastern routes, and native area (Rewicz et al., 2015a). This first simulation aimed to 
213 understand the source(s) of colonization of Alpine Lakes. A second simulation was restricted to the

214 dataset including the 12 Alpine Lakes populations only (Table 1). This simulation aimed to

215 understand how these lakes clustered at the Msat level, completing the mtDNA analyses. Run for

216 each K value ( 1 to 8 ) was repeated 10 times. Each run included 750000 iterations with a burn-in of

217500000 iterations. All simulations were performed using the admixture and correlated allele

218 frequencies models with no prior information. Selection of the most probable K value relied on the

$219 \Delta \mathrm{K}$ method developed by Evanno, Regnaut \& Goudet, (2005).

220 We also tested the hypothesis of a single introduction into one of the Alpine Lakes, followed by a

221 series of founder events according to a stepping-stone type of pattern of further expansion in other

222 lakes. Such a pattern would lead to increasing differentiation in allele frequencies relative to an

223 increasing the distance to the source. Based on the 12 lacustrine populations we therefore tested if

224 microsatellite differentiation increased positively with distance between sites (isolation-by-distance,

225 IBD). The geographic distances between lakes were estimated using Google Earth Pro7.1.5.1557.

226 The IBD was tested using Mantel's test between $F_{\mathrm{ST}} /\left(1-F_{\mathrm{ST}}\right)$ and geographic distance as

227 recommended by Rousset (2008) for testing IBD in one-dimensional linear systems, with 100000

228 permutations, using the GENEPOP on the Web 4.2 (Raymond \& Rousset, 1995) and ISOLDE

229 software.

230 As the result of the above analyses, we defined two groups of lakes where secondary spreads may

231 be suspected i.e. the Neuchâtel-group: Bienne (40L), Murten (39L), Neuchâtel (38L) and the

232 Zurich-group: Greifen (43L), Zurich (42L), Zug (41L); see results for details). The coalescence-

233 based program MIGRATE-N 3.6.8 (Beerli, 2006; Beerli, 2009) was used to estimate the intensity

234 and preferential direction of migration between pairs of locations within each of these groups. The

235 MIGRATE-N estimates the mutation-scaled migration rate $M(M=m / \mu$, where $m$ is the immigration

236 rate per generation and $\mu$ is the mutation rate) and population size $\Theta(4 \mathrm{Ne} \mu$, where $\mathrm{Ne}$ is effective

237 population size). All seven microsatellites loci were used in the analysis. The parameters were

238 inferred with Bayesian paradigm using the Brownian mutation model. The mutation rate among loci

239 was scaled so that the average change of the mutation rate was 1.0 and the relative mutation rates

240 were estimated for all loci. Initial $\mathrm{M}$ and $\Theta$ were calculated from $F_{\mathrm{ST}}$ estimates. Two runs were

241 performed, each with one chain consisting of 1000000 recorded steps (increment 100) replicated

242 four times. Altogether 400000000 parameter values were sampled and 100000 initial values per

243 chain were discarder as burn-in. 
246

247

Genetic diversity was assessed for each lacustrine population, for both mtDNA and Msat markers by calculating allelic richness $\left(A_{\mathrm{r}}\right)$ corrected for a common sampling size using a rarefaction approach (Leberg, 2002). Calculations were performed with HP-RARE 1.1 (Kalinowski, 2005). In addition, expected heterozygosity $\left(H_{\mathrm{E}}\right)$ was calculated for microsatellite markers using FSTAT (Goudet, 2001). Both parameters $\left(A_{\mathrm{r}}\right.$ and $\left.H_{\mathrm{E}}\right)$ were compared to 11 geographically closest populations (sites 14, 15, 17-19, 21, 22, 24-27) from the western route as defined by Rewicz et al. (2015a), to track the potential loss of genetic diversity. This comparison was restricted to populations from the western route on the basis of the analysis showing that this route was the only source of the colonization of Alpine Lakes (see results). Differences in $A_{\mathrm{r}}$ and $H_{\mathrm{E}}$ were tested using non-parametric Wilcoxon rank test in STATISTICA 10 (StatSoft Inc., 2011).

A method implemented in the BOTTLENECK v1.2.02 software (Cornuet \& Luikart, 1996; Piry, Luikart \& Cornuet, 1999), using summary statistics of the genetic diversity to assess significant deviations from mutation/drift equilibrium, was applied. Heterozygosity excess was considered as evidence of recent bottlenecks (or founder effect in the present situation) (Luikart \& Cornuet, 1998). Presence of heterozygote excess was tested under the three following mutation models: infinite alleles (IAM), two-phase (TPM), and the step-wise (SMM). For TPM we set ps $=0.95$ (the frequency of single step mutations) and the variance of those mutations as 12. Significance for all models was tested using Wilcoxon's signed rank tests. Altogether 100000 simulations were run. To account for multiple comparisons, the FDR procedure was applied (Benjamini \& Yekutieli, 2001; Narum, 2006).

In addition, following Luikart et al. (1998) and as applied by Wattier et al. (2007), the number of alleles over all microsatellite loci according to allele frequencies in native and invaded areas was plotted. Bottlenecks are expected to reduce the number of rare alleles (frequency $<0.1$ in the native range), therefore shifting the mode of the allele frequency histogram towards alleles with higher frequencies. We therefore compared the distribution of allele frequencies of the 12 Alpine lake populations with those of the closest populations located on the Western route, on Danube or Rhine or Rhône waterways, surrounding the Alpine arc (populations 15, 17, 19 and 27, see Fig. 1). Comparisons were made using non parametric test of Dunn with Control for Joint Ranks. Since all populations of the Western route showed the same allele distribution frequencies (Wilconxon rank test: $\chi 2=6.75,3$ d.f., $\mathrm{P}=0.09$ ), we chose to illustrate this comparison with the closest from our Alpine lake data set: population 19 (Figure 2a). In accordance with the results of Bącela-Spychalska et al. (2013) we may expect the overland transportation with leisure activity to be the most important vector of the killer shrimp to the Alpine Lakes. To test if the touristic pressure may be a proxy for the number and/or propagule size of 
280 introductions the allelic richness $\left(A_{\mathrm{r}}\right)$ of the populations inhabiting the particular Alpine Lake was

281 correlated with boat number and boat density (number of boats/lake area). The boat number for

282 each lake was counted by eye on Google Earth picture (Table 1, for details see Bącela-Spychalska

283 et al., 2013). A positive correlation between boat number/density and $A_{\mathrm{r}}$ was expected as increasing

284 probability of $D$. villosus translocation would allow rare alleles to be incorporated. In addition,

285 because recently-founded populations may show the weakest genetic diversity, we tested correlation 286 between $A_{\mathrm{r}}$ and the possible 'age' of the killer shrimp populations, i.e. years between the first record 287 in each lake and the year of sampling. It was tested by Spearman correlation test.

\section{Results}

Western route as the only source for populations established in the Alpine Lakes

291 Based on the concatenated $16 \mathrm{~S}$ and COI mtDNA sequences, six haplotypes $\left(\mathrm{n}^{\circ} 1,2,17,18,19\right.$ and 292 20) were identified out of 128 analysed individuals from all the twelve Alpine Lakes (Fig. 2a, Table 293 S1). The relatively abundant haplotype 13, specific for the eastern native area and route, was not 294 found in any of the lakes. Haplotype 19 observed in lakes: Zug (41L), Zurich (42L) and Greifen 295 (43L), and haplotype 20 found in Lake Geneva (44L) were not recorded by Rewicz et al. (2015a) 296 neither in native areas, nor in the eastern or western route of invasion. The Msat Bayesian clustering

297 from our first simulation clearly showed that all Alpine populations (34L-45L) cluster together with 298 those from the western invasion route ( $\left.\operatorname{sites} n^{\circ} 12-31\right)$ and the associated native area in the Danube

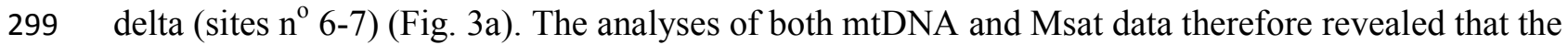
300 eastern native area and the associated route can be excluded as a source for populations established 301 in the Alpine Lakes.

302

303 304

305 306 307 308 309 310

Independent founder events in different regions of the Alps and secondary spread between some Alpine Lakes

Four main clusters were observed in Alpine Lakes based on the similarity of their mtDNA haplotypes. The first cluster consisted of the "'Zurich-group'" (Zug - 41L, Zurich - 42L and Greifen - 43L), while the second one was composed of the "Neuchâtel -group" (Neuchâtel - 38L, Murten 39L and Bienne - 40L). These groups shared mtDNA haplotypes either rare or even absent elsewhere (Fig. 2a). A third cluster consisted of the Geneva Lake (44L) and the Bourget Lake (45L) (“Geneva-group"), both sharing a rare haplotype present in the western route (Fig. 2). The last 
311 cluster consisted of the remaining lakes (34L, 35L, 36L and 37L) sharing only the most common

312 haplotype 1 . Thus, this last clustering was not really informative.

313 The STRUCTURE analysis of Msat data restricted to Alpine Lakes provided more precise

314 information on the above clustering. First, it confirmed the assignment of lakes clustered within the

315 "Zurich-group", the "Neuchâtel -group" and the "Geneva-group". However, the remaining lakes

316 were assigned to different genetic units (Fig. 3b). First, Lake Traun (34L) was recognised as

317 belonging to the "Zurich-group" by STRUCTURE, but did not share the peculiar composition of

318 mtDNA haplotypes characteristic of other lakes from this group (see above, Fig. 2). In addition, the

$319 F_{S T}$ values between the Lake Traun and the other lakes from the Zurich group were relatively high

$320\left(0.043<F_{S T}<0.054\right)$. This pattern advocates for an independent colonization event in this lake

321 compared to the Zurich group. Second, lakes 35, 36 and 37L, while sharing the same mtDNA

322 haplotypes with 34L, were clearly assigned to a different Msat unit, and cannot be clearly assigned

323 to the previously identified genetic units (these lakes were somehow between Geneva and

324 Neuchâtel groups).

325 Within the "Neuchâtel-group", "Geneva-group" and "Zurich-group" (Lake Traun being excluded

326 from the later, see above), the values of $F_{S T}$ or $\Phi$ st between lakes were low and mostly not

327 significant, while they were highly significant between lakes from the other groups (Table 2).

328 Among the remaining lakes, the only non-significant $F_{S T}$ were between Lake Garda (36L) and Iseo

329 (37L), suggesting high gene flow between these two lakes only (Table 2).

330 The analysis performed in MIGRATE-N detected high migration rates between lakes within

331 Neuchâtel and Zurich groups. However, no asymmetry in gene flow pattern suggesting one peculiar

332 lake to be a source was observed (Table S2).

333 Finally, no significant correlation was detected between pairwise geographical distances and genetic

334 differentiation among Alpine Lakes (Mantel test, $\mathrm{R}=-0.042, \mathrm{p}=0.74$ ). A single introduction of $D$.

335 villosus into one of the lakes followed by a series of founder events was therefore unlikely.

336 In summary, by combining mtDNA and microsatellite data we revealed that colonization of the

337 Alpine Lakes was complex, with multiple independent population founding from the western route

338 and secondary spread or admixture among some lakes. We may suggest that six independent

339 founding event occurred: in the Genava-group, the Neuchâtel-group, the Zurich-group, in Garda-

340 Iseo, in the Lake Constance and in the Lake Traun. 
342

343

344

345

346

347

348

349

350

351

352

353

354

355

356

357

358

359

360

361

362

363

364

365

366

367

368

369

370

371

372

An overall reduction of $D$. villosus genetic diversity in the Alpine Lakes

Allelic richness $\left(A_{\mathrm{r}}\right)$ and the expected heterozygosity $\left(H_{\mathrm{E}}\right)$ values of the Alpine Lakes populations were significantly lower from those of the geographically closest populations from the western invasion route $\left(A_{\mathrm{r}}: \mathrm{Z}=2.93 \mathrm{p}=0.003 ; \mathrm{H}_{\mathrm{E}}: \mathrm{Z}=2.85, \mathrm{p}=0.004\right)$ (Figs $\left.4 \mathrm{a}, 4 \mathrm{~b}\right)$. The highest Msat diversity was observed in the Lake Garda (36L) and Lake Constance (35L) ( $A_{\mathrm{r}}=3.5$ and 3.43, respectively), while the lowest diversity was detected in the lakes: Bourget $(45 \mathrm{~L})$, Traun $(34 \mathrm{~L})$ and Geneva (44L) $\left(A_{\mathrm{r}}=2.35 ; 2.39 ; 2.42\right)$.

Genetic bottlenecks were evidenced in ten lakes: Traun (34L), Constance (35L), Garda (36L), Iseo (37L), Neuchâtel (38L), Murten (39L), Bienne (40L), Zug (41L), Zurich (42L), Greifen (43L)) under IAM model, in four lakes (Constance (35L), Neuchâtel (38L), Bienne (40L), Zurich (42L)) under TPM model, and in two lakes: Bienne (40L) and Zurich (42L), under SMM model (Table 1).

Cumulative distribution of allele frequencies showed mode shift for rare alleles (frequency $<0.1$ ) in three to seven lakes, depending on the Western route population used as control (Table S3, Fig. 5). Lakes of Geneva (44L), Traun (34L) and Bourget (45L) are those showing a significant difference in allele distribution in all cases, while lakes Greifen (43L), Zurich (42L), Zug (41L) and Neuchatel (38L) showed significant shifts for rare alleles depending on the population used as control (Table S3).

No correlation (Spearman correlation $\mathrm{r}=0.39, \mathrm{p}=<0.05$ ) was found between $A_{\mathrm{r}}$ and the possible 'age' of the killer shrimp populations, i.e. years between the first record in each lake and the year of sampling. No correlation was found neither between $A_{\mathrm{r}}$ of populations inhabiting the Alpine Lakes and the number of boats (Spearman correlation $\mathrm{r}=0.33, \mathrm{p}=<0.05$ ), nor between $A_{\mathrm{r}}$ and the boat density (Spearman correlation $r=-0.24, p=<0.05$ ).

\section{Discussion}

Many molecular studies help to reveal origins, founder events and secondary spreading of freshwater alien species (Ficetola, Bonin \& Miaud, 2008), e.g. gobiid fishes (Bronnenhuber et al., 2011; Grabowski et al., 2016), bivalves (Zhan et al., 2012) or gammarids (Cristescu et al., 2004). However, such studies are very scarce not only for the Alpine Lakes (Schmidlin et al., 2012) but also for the Alpine terrestrial ecosystems (Henry et al., 2009). Here, we evidenced that colonization of the Alpine Lakes by Dikerogammarus villosus resulted from a process contrasting with the one evidenced for rivers in continental Europe (Rewicz et al., 2015a). This colonization in the Alps 
373 originated from several independent introductions but from a single route of invasion, followed by

374 secondary spreads among neighboring lakes. This pattern induced an overall decrease in genetic

375 diversity compared to the pattern observed in the invasion routes.

376

377

378

379

380

381

382

383

384

385

386

387

388

389

390

391

392

393

394

395

396

397

398

399

400

401

402

403

404

\section{The western route as the only source of invasion}

Rewicz et al. (2015a) identified two invasion routes for D. villosus in continental lowland Europe (see Fig. 1a). The comparison between native and invaded areas in each route revealed an absence of loss of genetic diversity and, generally, the lack of genetic differentiation. High propagule pressure associated with large propagule size and/or recurrent waves of migration may explain the observed pattern. All the waterways associated with both invasion routes were already recognized as effective invasion highways for Ponto-Caspian invasive species (Bij de Vaate et al., 2002; Jażdżewski, 1980; Leuven et al., 2009; Panov et al., 2009).

Our present results, combining mtDNA and Msat markers, showed clearly that the western route was the only source for the colonization of the Alpine Lakes by the killer shrimp (Figs 2b, 3a). The western route is geographically closer to the Alpine Lakes if compared to the eastern one, and there are direct hydrological connections between the western route and some of the Alpine Lakes. For example, Lake Geneva is directly connected to the Rhône River, and Lake Bourget is connected to Rhône by the $4.1 \mathrm{~km}$ long navigable Canal de Savières. On the other hand, the two Italian lakes, Lake Garda and Lake Iseo, located in the southern part of the Alps, are far away from the western invasion route and without any direct aquatic connection. They were nevertheless colonized by the killer shrimp (in 2003 and 2011, respectively). Here, instead of a direct colonization via hydrological connection, overland transport with leisure boats is a more probable vector for its introduction to these lakes. Other possible vectors of introduction to these isolated waterbodies may be birds, e.g. waterfowls, as evidenced for several amphipod species (Rachalewski et al., 2013 and references cited therein). However, the occurrence of D. villosus in the Alpine Lakes is closely associated with the intensity of recreational boating as shown by our previous studies (BącelaSpychalska et al., 2013) and a high risk of spread with angling, sailing and diving equipment has already been demonstrated (Anderson et al., 2014). Touristic pressure is very high in the Alpine region (Pechlaner \& Tschurtschenthaler, 2003) and exchange of boats between various, sometimes very distinct regions, happens quite often. Lakes such as Garda, Neuchâtel, Geneva and Constance, are the biggest hubs for boat transport in the Alps (de Ventura et al., 2016). An overland transport is among the essential vectors for worldwide spread of other invasive species such as the Corbicula 
405 clams (Schmidlin et al., 2012), zebra mussel Dreissena polymorpha (Pallas, 1771) (de Ventura et 406 al., 2016), or the aquatic plant Cabomba caroliniana (Gray 1837) (Bickel, 2015).

407 Our results suggest that the eastern invasion route of $D$. villosus cannot be a source of introduction 408 to the Alpine Lakes. Since this route is not connected directly with Alpine Lakes investigated here, 409 the only potential way of colonization would have been an overland transport of recreational boats 410 from central-eastern Europe. This cannot be excluded because D. villosus is known to resist adverse 411 conditions associated with overland transport for a time compatible with long distance transport 412 (Martens \& Grabow, 2008). However, touristic boat translocations are rare from countries 413 associated with the eastern invasion route of $D$. villosus (de Ventura et al., 2016). Yet, the transport 414 of $D$. villosus from the eastern route may perhaps be only a matter of time. It is to be noticed that 415 the killer shrimp recently invaded the Masurian Lake District (MLD) in north eastern Poland (own 416 unpublished data), which is directly connected to the eastern route. This district is highly

417 fashionable for sailing and boating, with frequent relocation of boats both among lakes within the 418 area and among MLD and foreign lakes, including the Alpine ones (personal communication, yacht 419 transport company).

\section{Several independent founding events and cases of secondary spread or admixture}

422 Based on Msat data, several genetic clusters were defined, with low within- and high between423 cluster genetic differentiations (Fig. 3b, Table 2). This result is reinforced by mtDNA data (Fig. 2b). 424 Such a pattern may be explained by either a single introduction followed by a progressive 425 colonization from this single source, by a massive colonization of this area followed by only small 426 success of founding populations, or by recurrent and independent attempts for colonization with few 427 founding populations, leading to independent colonization events. The absence of correlation 428 between geographic distance and Fst suggest that a single introduction followed by a series of 429 founder events (stepping-stone type pattern) is unlikely. A single massive colonization event is 430 highly improbable as well. Indeed, even if the western route is the only source for invasion in the 431 Alpine Lakes, only few lakes are directly connected to the main invasion route (Danube and low 432 part of Rhine). In addition, only few lakes connected to the Danube drainage harbour D. villosus 433 (Fig. 1b). Owing to the different genetic clusters deduced for both the mtDNA and Msat, it is 434 probable that colonization attempts occurred recurrently, followed by very few settlements. These 435 attempts were probably not simultaneous and could therefore initiate from various local populations 436 along the western route. They would be independent introductions or at least independent founder events. The propagule size could be small, strengthening the founder effects, reshuffling allele 
438 frequencies and promoting the observed genetic differentiation. This result contrasts with the 439 absence of genetic structure along the western route which can, on the opposite, be associated with 440 recurrent invasions and/or large propagule size (Rewicz et al., 2015a; Wattier et al., 2007).

Many lakes in the Alps are geographically aggregated. Assuming that a given lake is exposed to an introduction as a consequence of touristic pressure, the probability of secondary introduction to neighbouring and connected lakes is therefore predicted to be high. Our results suggest such independent founding events and secondary spread or admixture in two groups of lakes: i) the Neuchâtel-group: Neuchâtel (38L), Murten (39L), Bienne (40L) and ii) the Zurich-group: Zug (41L), Zurich (42L), Greifen (43L). Each group combined the signature of an absence of withingroup genetic differentiation while being differentiated from other lakes.

This within-group lack of genetic differentiation indicates that, after a colonization event within each group, there was gene flow between lakes belonging to the group. The lakes of the Neuchatel group are interconnected by a system of canals: Lake Murten is connected to Lake Neuchâtel by the Broye Canal and Lake Neuchâtel is connected to Lake Bienne by the Thielle canal. The latter lake drains to the River Aare which ends in the River Rhine. These three lakes form a kind of system of reservoirs to control water level. Thus, occasionally, the water from Lake Bienne flows backwards through the Thielle and Broye canals in order to retain the overflow from the river Aare (Cioc, 2009). Whatever the scenario of D. villosus introduction to these lakes, either these direct connexions or the high touristic pressure and boat traffic on the Lake Neuchâtel (de Ventura et al., 2016) may explain intense genetic flow within this group of lakes. The observed bottleneck supports a scenario with a small initial population, probably a single settlement in one of these lakes. However, the results of the migration pattern analysis did not allow to identify any particular lake as being the one colonized first. In the 'Zurich group' of lakes, the lack of differentiation and symmetrical migration pattern also suggests very large or/and multiple transfers of the killer shrimp among these lakes and also prevents, based on the current data, identification which of the lakes was colonised first. Even if there is no direct hydrological connection between these lakes, their geographic proximity suggest that the secondary spreads may have occurred through overland transport. Considering the Neuchâtel group, the similarity in haplotype or allele frequencies among lakes also suggests an intense and continuous gene flow among these lakes since their first colonization.

Overall reduction in genetic diversity 
470 The overall genetic diversity of $D$. villosus populations in the Alpine Lakes was significantly lower

471 in comparison to populations from the western route. The bottleneck effect was detected in $25 \%$ to

$47275 \%$ of the twelve investigated lakes. The proportion of lakes where bottlenecks were detected was

473 highly dependent on the method used for detection. The relatively low number of Msat available for

474 D. villosus is probably the cause for the variation observed in the proportion of bottleneck detection.

475 No correlation was found between allelic richness of populations inhabiting Alpine Lakes and the

476 age since colonization. For example, Lake Traun, sampled eight years after its colonisation, still had

477 very low genetic diversity. Additionally, loss of genetic diversity does not seem to be the only result

478 of lake isolation from the western route. For example, populations from the isolated Lake Garda and

479 Lake Iseo did not suffer large reduction of genetic diversity. Lake Garda has the highest level of

480 allelic richness among the studied lakes. No correlation was found in the Alpine Lakes between

481 allelic richness and (i) the number of boats, (ii) the boat density, which could have explain higher

482 propagule size at the time of introduction. The diverse patterns of genetic diversity found in our

483 study illustrates the complex colonization pattern of the Alpine Lakes compared to the invasion

484 highways.

485 The short term ecological success of the killer shrimp was not impeded by reduced genetic

486 diversity. This case is not an isolated one. Populations of species such as the gammarid

487 Echinogammarus ischnus (Stebbing, 1899) (Cristescu et al., 2004), cladoceran Cercopagis pengoi

488 (Ostroumov, 1891) (Cristescu et al., 2001), mysid Hemimysis anomala G. O. Sars, 1907

489 (Audzijonyte, Wittmann \& Vainola, 2008) or guppy fish Poecilia reticulata W. K. H. Peters, 1859

490 (Lindholm et al., 2005) experience founder effects and bottlenecks without any negative

491 consequences. A mechanism explaining such patterns could be a purge of recessive deleterious

492 alleles, which fuelled further population expansion, as evidenced in the ladybird Harmonia axyridis

493 (Pallas, 1773) (Facon et al., 2011). Reduction of genetic diversity was also observed in populations

494 of D. villosus after the colonization of waterbodies in the UK (Arundell et al., 2015; Rewicz et al.,

495 2015a). Since the first initial population was discovered in 2010, the killer shrimp was detected in

496 further four localities (MacNeil et al., 2010). Its surprisingly slow spread in UK compared to the

497 Alpine Lakes, can be explained by the effective implementation of 'check, clean and dry' procedure

498 (Arundell et al., 2015).

499

500 Conservation implications

501 Among the Ponto-Caspian invaders, D. villosus is considered as one of the most deleterious for

502 local fauna (Bij de Vaate et al., 2002; Rewicz et al., 2014). In the Alpine Lakes, negative impact of 
503 D. villosus on the native ecosystems in already known. It includes displacing the native amphipod 504 Echinogammarus stammeri (S. Karaman, 1931) in lake Garda (Casellato, Visentin \& La Piana, 505 2007), Gammarus pulex (Linnaeus, 1758) and Gammarus fossarum Koch, 1836 in the Lake Zurich 506 (Steinmann, 2008) and Gammarus roeselii Gervais, 1835 in Lake Constance (Gergs, Schlag \& 507 Rothhaupt, 2013). Decrease of the whitefish Coregonus lavaretus (Linnaeus, 1758) population in 508 the Lake Garda also followed invasion of the killer shrimp (Casellato, Visentin \& La Piana, 2007).

509 Currently, at least twelve lakes are invaded by the killer shrimp in the Alpine region (Bącela510 Spychalska et al., 2013). High touristic pressure and intense overland transport of boats and water 511 sport gear may promote its further spread (Bącela-Spychalska et al., 2013; de Ventura et al., 2016). 512 As clearly evidenced for the Zurich and Neuchâtel lakes groups, such secondary spread may be a 513 fast process.

514 Eradication of invasive aquatic macroinvertebrates such as D. villosus without heavy damage to the 515 entire ecosystem is extremely difficult, expensive, or even impossible (Genovesi, 2005). Only few 516 successful examples of eradication of aquatic invertebrates are known e.g. rusty crayfish 517 (Orconectes rusticus (Girard, 1852)) from the Sparkling Lake, Wisconsin (LTER, 2014). Thus, 518 some measures should be implemented to avoid further expansion. Some countries like United 519 Kingdom, New Zealand, Canada and the United States of America have implemented programs 520 which may prevent or reduce the chance of transferring invasive species with relocation of yachts, 521 and other sport gear (Anderson et al., 2015). These programs are generally called 'check, clean and 522 dry' and they are addressed to tourists, anglers etc., to aware them about the threats from invasive 523 species (Aldridge, Ho \& Froufe, 2014; StateDept, 2015). These procedures are easy to implement 524 and should be forced immediately in the Alpine marinas to prevent spreading of the killer shrimp 525 and other invasive species. Stopping the expansion of invasive species in lacustrine ecosystems 526 should be a primary objective due to their detrimental impact on local biota.

\section{Acknowledgment}

529 The study was financed by the Polish Ministry for Science and Higher Education, grant no. N 530 N304350139 and partially from the internal funds of the University of Lodz. Thanks are due to 531 Alicja Konopacka for help in sampling, Uta Mürle from HYDRA, Germany for providing us the 532 samples from the Constance Lake, and Sandra Casellato for providing us the samples from Garda 533 Lake. 


\section{References}

536

537

538

539

540

541

542

543

544

545

546

547

548

549

550

551

552

553

554

555

556

557

558

559

560

561

562

563

564

565

566

567

568

569

570

571

572

573

574

575

576

577

578

579

580

581

582

583

584
Adebayo A.A., Zhan A., Bailey S.A. \& Macisaac H.J. (2014) Domestic ships as a potential pathway of nonindigenous species from the Saint Lawrence River to the Great Lakes. Biological Invasions, 16, 793-801.

Aldridge D.C., Ho S. \& Froufe E. (2014) The Ponto-Caspian quagga mussel, Dreissena rostriformis bugensis (Andrusov, 1897), invades Great Britain. Aquatic Invasions, 9, 529-535.

Altermatt F., Alther R., Fišer C., Jokela J., Konec M., Küry D., Mächler E., Stucki P. \& Westram A.M. (2014) Diversity and distribution of freshwater amphipod species in Switzerland (Crustacea: Amphipoda). PLoS One, 9.

Anderson L.G., Dunn A.M., Rosewarne P.J. \& Stebbing P.D. (2015) Invaders in hot water: A simple decontamination method to prevent the accidental spread of aquatic invasive nonnative species. Biological Invasions, 17, 2287-2297.

Anderson L.G., White P.C.L., Stebbing P.D., Stentiford G.D. \& Dunn A.M. (2014) Biosecurity and vector behaviour: Evaluating the potential threat posed by anglers and canoeists as pathways for the spread of invasive non-native species and pathogens. PLoS One, 9.

Arundell K., Dunn A., Alexander J., Shearman R., Archer N. \& Ironside J.E. (2015) Enemy release and genetic founder effects in invasive killer shrimp populations of Great Britain. Biological Invasions, 17, 1439-1451.

Audzijonyte A., Wittmann K.J. \& Vainola R. (2008) Tracing recent invasions of the Ponto-Caspian mysid shrimp Hemimysis anomala across Europe and to North America with mitochondrial DNA. Diversity and Distributions, 14, 179-186.

Bącela-Spychalska K. (2016) Attachment ability of two invasive amphipod species may promote their spread by overland transport. Aquatic Conservation: Marine and Freshwater

Ecosystems, 26, 196-201.

Bącela-Spychalska K., Wattier R.A., Genton C. \& Rigaud T. (2012) Microsporidian disease of the invasive amphipod Dikerogammarus villosus and the potential for its transfer to local invertebrate fauna. Biological Invasions, 14, 1831-1842.

Bącela-Spychalska K., Grabowski M., Rewicz T., Konopacka A. \& Wattier R. (2013) The "killer shrimp' Dikerogammarus villosus (Crustacea, Amphipoda) invading Alpine lakes: overland transport by recreational boats and scuba-diving gear as potential entry vectors? Aquatic Conservation-Marine and Freshwater Ecosystems, 23, 606-618.

Barbashova M.A., Malavin S.A. \& Kurashov E.A. (2013) First finding of Baikalian amphipod Micruropus possolskii Sowinsky, 1915 (Amphipoda, Crustacea) in Lake Ladoga. Russian Journal of Biological Invasions, 4, 219-224.

Beerli P. (2006) Comparison of Bayesian and maximum-likelihood inference of population genetic parameters. Bioinformatics, 22, 341-345.

Beerli P. (2009) How to use MIGRATE or why are Markov chain monte Carlo programs difficult to use? In: Population Genetics for Animal Conservation pp. 42-79.

Benjamini Y. \& Yekutieli D. (2001) The control of the false discovery rate in multiple testing under dependency. Annals of Statistics, 29, 1165-1188.

Bickel T.O. (2015) A boat hitchhiker's guide to survival: Cabomba caroliniana desiccation resistance and survival ability. Hydrobiologia, 746, 123-134.

Bij De Vaate A., Jazdzewski K., Ketelaars H.a.M., Gollasch S. \& Van Der Velde G. (2002) Geographical patterns in range extension of Ponto-Caspian macroinvertebrate species in Europe. Canadian Journal of Fisheries and Aquatic Sciences, 59, 1159-1174.

Bollache L. (2004) Dikerogammarus villosus (Crustacea: Amphipoda): another invasive species in Lake Geneva. Revue Suisse De Zoologie, 111, 309-313.

Bronnenhuber J.E., Dufour B.A., Higgs D.M. \& Heath D.D. (2011) Dispersal strategies, secondary range expansion and invasion genetics of the nonindigenous round goby, Neogobius melanostomus, in Great Lakes tributaries. Molecular Ecology, 20, 1845-1859. 
Bruijs M.C.M., Kelleher B., Van Der Velde G. \& De Vaate A.B. (2001) Oxygen consumption, temperature and salinity tolerance of the invasive amphipod Dikerogammarus villosus: indicators of further dispersal via ballast water transport. Archiv Fur Hydrobiologie, 152, 633-646.

Buric M., Koci L., Petrusek A., Kouba A. \& Kozak P. (2009) Invaders eating invaders: potential trophic interactions between the amphipod Dikerogammarus villosus and juvenile crayfish Orconectes limosus. Knowledge and Management of Aquatic Ecosystems.

Casellato S., La Piana G., Latella L. \& Ruffo S. (2006) Dikerogammarus villosus (Sowinsky, 1894) (Crustacea, Amphipoda, Gammaridae) for the first time in Italy. Italian Journal of Zoology, 73, 97-104.

Casellato S., Visentin A. \& La Piana G. (2007) The predatory impact of Dikerogammarus villosus, a danger for fish. In: Biological invaders in inland waters: profiles, distribution, and threats. Invading Nature: Springer Series in Invasion Ecology. (Ed F. Gherardi), pp. 495-506. Springer, Dordrecht, The Netherlands.

Chenna R., Sugawara H., Koike T., Lopez R., Gibson T.J., Higgins D.G. \& Thompson J.D. (2003) Multiple sequence alignment with the Clustal series of programs. Nucleic Acids Research, 31, 3497-3500.

Cioc M. (2009) The Rhine: an eco-biography, 1815-2000, University of Washington Press, Washington.

Cornuet J.M. \& Luikart G. (1996) Description and power analysis of two tests for detecting recent population bottlenecks from allele frequency data. Genetics, 144, 2001-2014.

Cristescu M.E.A., Hebert P.D.N., Witt J.D.S., Macisaac H.J. \& Grigorovich I.A. (2001) An invasion history for Cercopagis pengoi based on mitochondrial gene sequences. Limnology and Oceanography, 46, 224-229.

Cristescu M.E.A., Witt J.D.S., Grigorovich I.A., Hebert P.D.N. \& Macisaac H.J. (2004) Dispersal of the Ponto-Caspian amphipod Echinogammarus ischnus: invasion waves from the Pleistocene to the present. Heredity, 92, 197-203.

Cuddington K. \& Hastings A. (2004) Invasive engineers. Ecological Modelling, 178, 335-347.

Daisie. (2009) Handbook of Alien Species in Europe, Springer, Dordrecht, The Netherlands.

De Ventura L., Weissert N., Tobias R., Kopp K. \& Jokela J. (2016) Overland transport of recreational boats as a spreading vector of zebra mussel Dreissena polymorpha. Biological Invasions, 1-16.

Deredec A. \& Courchamp F. (2007) Importance of the Allee effect for reintroductions. Ecoscience, 14, 440-451.

Dick J.T.A. \& Platvoet D. (2000) Invading predatory crustacean Dikerogammarus villosus eliminates both native and exotic species. Proceedings of the Royal Society B-Biological Sciences, 267, 977-983.

Dlugosch K.M. \& Parker I.M. (2008) Founding events in species invasions: genetic variation, adaptive evolution, and the role of multiple introductions. Molecular Ecology, 17, 431-449.

Drake J.M. \& Lodge D.M. (2004) Global hot spots of biological invasions: Evaluating options for ballast-water management. Proceedings of the Royal Society B: Biological Sciences, 271, 575-580.

Evanno G., Regnaut S. \& Goudet J. (2005) Detecting the number of clusters of individuals using the software STRUCTURE: a simulation study. Molecular Ecology, 14, 2611-2620.

Excoffier L. \& Lischer H.E.L. (2010) Arlequin suite ver 3.5: a new series of programs to perform population genetics analyses under Linux and Windows. Molecular Ecology Resources, 10, 564-567.

Facon B., Hufbauer R.A., Tayeh A., Loiseau A., Lombaert E., Vitalis R., Guillemaud T., Lundgren J.G. \& Estoup A. (2011) Inbreeding depression is purged in the invasive insect harmonia axyridis. Current Biology, 21, 424-427. 
Folmer O., Black M., Hoeh W., Lutz R. \& Vrijenhoek R. (1994) DNA primers for amplification of mitochondrial cytochrome c oxidase subunit I from diverse metazoan invertebrates. Molecular marine biology and biotechnology, 3, 294-299.

Forsman A. (2014) Effects of genotypic and phenotypic variation on establishment are important for conservation, invasion, and infection biology. Proceedings of the National Academy of Sciences of the United States of America, 111, 302-307.

Funnell E., Heaton M., Macdonald F. \& Brownson B. (2009) The aquarium and horticultural industry as a pathway for the introduction of aquatic invasive species - outreach initiatives within the Great Lakes basin. Biodiversity, 10, 104-112.

Genovesi P. (2005) Eradications of invasive alien species in Europe: A review. Biological Invasions, 7, 127-133.

Genton B.J., Shykoff J.A. \& Giraud T. (2005) High genetic diversity in French invasive populations of common ragweed, Ambrosia artemisiifolia, as a result of multiple sources of introduction. Molecular Ecology, 14, 4275-4285.

Gergs R., Schlag L. \& Rothhaupt K.O. (2013) Different ammonia tolerances may facilitate spatial coexistence of Gammarus roeselii and the strong invader Dikerogammarus villosus. Biological Invasions, 15, 1783-1793.

Goudet J. (2001) FSTAT, a program to estimate and test gene diversities and fixation indices. http://www2.unil.ch/popgen/softwares/fstat.htm.

Grabowski M., Bącela K. \& Konopacka A. (2007a) How to be an invasive gammarid (Amphipoda : Gammaroidea)-comparison of life history traits. Hydrobiologia, 590, 75-84.

Grabowski M., Bącela K. \& Wattier R. (2007b) Dikerogammarus villosus (Sovinsky, 1894) (Crustacea, Amphipoda) colonizes next alpine lake - Lac du Bourget, France. Aquatic Invasions, 2, 268-271.

Grabowski M., Hupało K., Bylak A., Kukuła K. \& Grabowska J. (2016) Double origin of the racer goby (Babka gymnotrachelus) in Poland revealed with mitochondrial marker. Possible implications for the species alien/native status. Journal of Limnology, 75, 101-108.

Grabowski M., Rewicz T., Bącela-Spychalska K., Konopacka A., Mamos T. \& Jazdzewski K. (2012) Cryptic invasion of Baltic lowlands by freshwater amphipod of Pontic origin. Aquatic Invasions, 7, 337-346.

Henry P., Le Lay G., Goudet J., Guisan A., Jahodová S. \& Besnard G. (2009) Reduced genetic diversity, increased isolation and multiple introductions of invasive giant hogweed in the western Swiss Alps. Molecular Ecology, 18, 2819-2831.

Hillis D.M., Moritz C. \& Mable B.K. (1996) Molecular Systematics, Second edition, Sinauer Associates Inc, Sunderland, MA, USA.

Holdich D.M. \& Pöckl M. (2007) Invasive crustaceans in European inland waters. In: Biological invaders in inland waters: profiles, distribution and threats. (Ed F. Gherardi), pp. 29-75. Springer, Berlin.

Holeck K.T., Mills E.L., Macisaac H.J., Dochoda M.R., Colautti R.I. \& Ricciardi A. (2004) Bridging troubled waters: Biological invasions, transoceanic shipping, and the Laurentian Great Lakes. BioScience, 54, 919-929.

Hou Z.G., Fu J.H. \& Li S.Q. (2007) A molecular phylogeny of the genus Gammarus (Crustacea : Amphipoda) based on mitochondrial and nuclear gene sequences. Molecular Phylogenetics and Evolution, 45, 596-611.

Jażdżewski K. (1980) Range extensions of some gammaridean species in European inland waters caused by human activity. Crustaceana Supplement, 6, 84-107.

Johnson L.E., Bossenbroek J.M. \& Kraft C.E. (2006) Patterns and pathways in the postestablishment spread of non-indigenous aquatic species: The slowing invasion of North American inland lakes by the zebra mussel. Biological Invasions, 8, 475-489.

Johnson L.E., Ricciardi A. \& Carlton J.T. (2001) Overland dispersal of aquatic invasive species: A risk assessment of transient recreational boating. Ecological Applications, 11, 1789-1799. 
Kakareko T., Kobak J., Grabowska J., Jermacz L., Przybylski M., Poznanska M., Pietraszewski D.

689

690

691

692

693

694

695

696

697

698

699

700

701

702

703

704

705

706

707

708

709

710

711

712

713

714

715

716

717

718

719

720

721

722

723

724

725

726

727

728

729

730

731

732

733

734

735

736

737

738

739
\& Copp G.H. (2013) Competitive interactions for food resources between invasive racer goby Babka gymnotrachelus and native European bullhead Cottus gobio. Biological Invasions, 15, 2519-2530.

Kalinowski S.T. (2005) HP-RARE 1.0: a computer program for performing rarefaction on measures of allelic richness. Molecular Ecology Notes, 5, 187-189.

Kerfoot W.C., Yousef F., Hobmeier M.M., Maki R.P., Jarnagin S.T. \& Churchill J.H. (2011) Temperature, recreational fishing and diapause egg connections: Dispersal of spiny water fleas (Bythotrephes longimanus). Biological Invasions, 13, 2513-2531.

Kinzler W. \& Maier G. (2006) Selective predation by fish: A further reason for the decline of native gammarids in the presence of invasives? Journal of Limnology, 65, 27-34.

Kolbe J.J., Glor R.E., Schettino L.R., Lara A.C., Larson A. \& Losos J.B. (2004) Genetic variation increases during biological invasion by a Cuban lizard. Nature, 431, 177-181.

Lavergne S. \& Molofsky J. (2007) Increased genetic variation and evolutionary potential drive the success of an invasive grass. Proceedings of the National Academy of Sciences of the United States of America, 104, 3883-3888.

Leberg P.L. (2002) Estimating allelic richness: Effects of sample size and bottlenecks. Molecular Ecology, 11, 2445-2449.

Leuven R.S.E.W., Van Der Velde G., Baijens I., Snijders J., Van Der Zwart C., Lenders H.J.R. \& De Vaate A.B. (2009) The river Rhine: a global highway for dispersal of aquatic invasive species. Biological Invasions, 11, 1989-2008.

Librado P. \& Rozas J. (2009) DnaSP v5: a software for comprehensive analysis of DNA polymorphism data. Bioinformatics, 25, 1451-1452.

Lindholm A.K., Breden F., Alexander H.J., Chan W.K., Thakurta S.G. \& Brooks R. (2005) Invasion success and genetic diversity of introduced populations of guppies Poecilia reticulata in Australia. Molecular Ecology, 14, 3671-3682.

Lockwood J.L., Cassey P. \& Blackburn T. (2005) The role of propagule pressure in explaining species invasions. Trends in Ecology \& Evolution, 20, 223-228.

Lods-Crozet B. \& Reymond O. (2006) Bathymetric expansion of an invasive gammarid (Dikerogammarus villosus, Crustacea, Amphipoda) in Lake Léman. Journal of Limnology, 65, 141-144.

Lombaert E., Guillemaud T., Thomas C.E., Lawson Handley L.J., Li J., Wang S., Pang H., Goryacheva I., Zakharov I.A., Jousselin E., Poland R.L., Migeon A., Van Lenteren J., De Clercq P., Berkvens N., Jones W. \& Estoup A. (2011) Inferring the origin of populations introduced from a genetically structured native range by approximate Bayesian computation: Case study of the invasive ladybird Harmonia axyridis. Molecular Ecology, 20, 4654-4670.

Lter U. (2014) Management of aquatic invasive species: rusty crayfish removal in Sparkling Lake. (Ed U.O.W.B.O. Regents). U.S. North Temperate Lakes Long Term Ecological Research network

Lubini V., Stucki P., Schiess H., Vincentini H. \& Wagner A. (2006) Révision des listes rouges nationales. Organismes aquatiques - MEPT (Mollusca, Ephemeroptera, Plecoptera et Trichoptera). p. 129. Rapport activité 2006, CSCF, Neuchâtel.

Luikart, G. et al. 1998. Distortion of allele frequency distributions provides a test for recent population bottlenecks. Journal of Hereidity, 89, 238_247.

Luikart G. \& Cornuet J.M. (1998) Empirical evaluation of a test for identifying recently bottlenecked populations from allele frequency data. Conservation Biology, 12, 228-237.

Macneil C., Dick J.T.A., Platvoet D. \& Briffa M. (2011) Direct and indirect effects of species displacements: an invading freshwater amphipod can disrupt leaf-litter processing and shredder efficiency. Journal of the North American Benthological Society, 30, 38-48.

Macneil C., Platvoet D., Dick J.T.A., Fielding N., Constable A., Hall N., Aldridge D., Renals T. \& Diamond M. (2010) The Ponto-Caspian 'killer shrimp', Dikerogammarus villosus (Sowinsky, 1894), invades the British Isles. Aquatic Invasions, 5, 441-445. 
740

741

742

743

744

745

746

747

748

749

750

751

752

753

754

755

756

757

758

759

760

761

762

763

764

765

766

767

768

769

770

771

772

773

774

775

776

777

778

779

780

781

782

783

784

785

786

787

788

789

790

Martens A. \& Grabow K. (2008) Das Risiko der Verschleppung neozoischer Amphipoda beim Überlandtransport von Yachten. Lauterbornia, 62, 41-44.

Muirhead J.R., Minton M.S., Miller W.A. \& Ruiz G.M. (2015) Projected effects of the Panama Canal expansion on shipping traffic and biological invasions. Diversity and Distributions, 21, 75-87.

Müller J.C., Schramm S. \& Seitz A. (2002) Genetic and morphological differentiation of Dikerogammarus invaders and their invasion history in Central Europe. Freshwater Biology, 47, 2039-2048.

Mürle U., Becker A. \& Seitz A. (2003) Ein neuer Flohkrebs im Bodensee: Dikerogammarus villosus (Grosser Höckerflohkrebs). http://bodensee-ufer.de.

Narum S.R. (2006) Beyond Bonferroni: Less conservative analyses for conservation genetics. Conservation Genetics, 7, 783-787.

Panov V.E., Alexandrov B., Arbačiauskas K., Binimelis R., Copp G.H., Grabowski M., Lucy F., Leuven R.S., Nehring S., Paunović M., Semenchenko V. \& Son M.O. (2009) Assessing the risks of aquatic species invasions via european inland waterways: From concepts to environmental indicators. Integrated Environmental Assessment and Management, 5, 110126.

Pechlaner H. \& Tschurtschenthaler P. (2003) Tourism policy, tourism organisations and change management in Alpine regions and destinations: A European perspective. Current Issues in Tourism, 6, 508-539.

Peeler E.J., Oidtmann B.C., Midtlyng P.J., Miossec L. \& Gozlan R.E. (2011) Non-native aquatic animals introductions have driven disease emergence in Europe. Biological Invasions, 13, 1291-1303.

Piry S., Luikart G. \& Cornuet J.M. (1999) BOTTLENECK: A computer program for detecting recent reductions in the effective population size using allele frequency data. Journal of Heredity, 90, 502-503.

Platvoet D., Van Der Velde G., Dick J.T.A. \& Li S.Q. (2009) Flexible omnivory in Dikerogammarus villosus (Sowinsky, 1894) (Amphipoda) - Amphipod Pilot Species Project (Ampis) Report 5. Crustaceana, 82, 703-720.

Pöckl M. (2007) Strategies of a successful new invader in European fresh waters: fecundity and reproductive potential of the Ponto-Caspian amphipod Dikerogammarus villosus in the Austrian Danube, compared with the indigenous Gammarus fossarum and G. roeseli. Freshwater Biology, 52, 50-63.

Pöckl M. (2009) Success of the invasive Ponto-Caspian amphipod Dikerogammarus villosus by life history traits and reproductive capacity. Biological Invasions, 11, 2021-2041.

Poulin R., Paterson R.A., Townsend C.R., Tompkins D.M. \& Kelly D.W. (2011) Biological invasions and the dynamics of endemic diseases in freshwater ecosystems. Freshwater Biology, 56, 676-688.

Pritchard J.K., Stephens M. \& Donnelly P. (2000) Inference of population structure using multilocus genotype data. Genetics, 155, 945-959.

Rachalewski M., Banha F., Grabowski M. \& Anastacio P. 2013. Ectozoochory as a possible vector enhancing the spread of an alien amphipod Crangonyx pseudogracilis. Hydrobiologia, 717, 109-117.

Raymond M.\& Rousset F. (1995) Genepop (Version-1.2)-Population-Genetics Software for ExactTests and Ecumenicism. Journal of Heredity, 86, 248-249.

Rewicz T., Grabowski M., Macneil C. \& Bącela-Spychalska K. (2014) The profile of a 'perfect' invader - the case of killer shrimp, Dikerogammarus villosus. Aquatic Invasions, 9, 267288.

Rewicz T., Wattier R., Grabowski M., Rigaud T. \& Bącela-Spychalska K. (2015a) Out of the Black Sea: phylogeography of the invasive killer shrimp Dikerogammarus villosus across Europe. PLoS One, 10, e0118121. 
Rewicz T., Wattier R.A., Rigaud T., Bącela-Spychalska K. \& Grabowski M. (2015b) Isolation and characterization of 8 microsatellite loci for the "killer shrimp", an invasive Ponto-Caspian amphipod Dikerogammarus villosus (Crustacea: Amphipoda). Molecular Biology Reports, 42, 13-17.

Ricciardi A. \& Rasmussen J.B. (1998) Predicting the identity and impact of future biological invaders: A priority for aquatic resource management. Canadian Journal of Fisheries and Aquatic Sciences, 55, 1759-1765.

Rodríguez C.F., Bécares E., Fernández-Aláez M. \& Fernández-Aláez C. (2005) Loss of diversity and degradation of wetlands as a result of introducing exotic crayfish. Biological Invasions, 7, $75-85$.

Roman J. \& Darling J.A. (2007) Paradox lost: genetic diversity and the success of aquatic invasions. Trends in Ecology \& Evolution, 22, 454-464.

Rousset F. (2008) Genepop'007: a complete reimplementation of the Genepop software for Windows and Linux. Molecular Ecology Resources, 8, 103-106.

Schmidlin S., Schmera D., Ursenbacher S. \& Baur B. (2012) Separate introductions but lack of genetic variability in the invasive clam Corbicula spp. in Swiss lakes. Aquatic Invasions, 7, 73-80.

Simberloff D., Martin J.L., Genovesi P., Maris V., Wardle D.A., Aronson J., Courchamp F., Galil B., Garcia-Berthou E., Pascal M., Pysek P., Sousa R., Tabacchi E. \& Vila M. (2013) Impacts of biological invasions: what's what and the way forward. Trends in Ecology \& Evolution, 28, 58-66.

StatSoft Inc. S (2011) STATISTICA (data analysis software system), version 10. www.statsoft.com.

Statedept N. (2015) A New York boaters guide to cleaning, drying and disinfecting boating equipment procedures to prevent the spread of aquatic invasive species while boating. New York State Department of Environmental Conservation

Steinmann P. (2008) Dikerogammarus villosus im Zürichsee und in der Limmat: Bestandesmonitoring 2007. Bericht zuhanden der Baudirektion des Kantons Zürich AWEL, Abteilung Gewässerschutz, 1-28.

Steinmann P. (2010) Neuester Fund: Dikerogammarus villosus im Zugersee. Aquatische Neozoen: http://www.psteinmann.net/neo_karten.html.

Steinmann P., Mürle U. \& Ortlepp J. (2006) Dikerogammarus villosus in der Aare und ihren Zuflüssen. Report, Hydra Büro für Gewasserökologie, Öschelbronn, 8.

Strayer D.L. (2010) Alien species in fresh waters: Ecological effects, interactions with other stressors, and prospects for the future. Freshwater Biology, 55, 152-174.

Tamura K. \& Nei M. (1993) Estimation of the Number of Nucleotide Substitutions in the Control Region of Mitochondrial-DNA in Humans and Chimpanzees. Molecular Biology and Evolution, 10, 512-526.

Van Der Velde G., Leuven R.S.E.W., Platvoet D., Bacela K., Huijbregts M.a.J., Hendriks H.W.M. \& Kruijt D. (2009) Environmental and morphological factors influencing predatory behaviour by invasive non-indigenous gammaridean species. Biological Invasions, 11, 2043-2054.

Van Kessel N., Dorenbosch M., De Boer M.R.M., Leuven R.S.E.W. \& Van Der Velde G. (2011) Competition for shelter between four invasive gobiids and two native benthic fish species. Current Zoology, 57, 844-851

van Oosterhout C., Hutchinson W.F., Wills D.P.M. \& Shipley P (2004) Micro-checker: software for identifying and correcting genotyping errors in microsatellite data. Molecular Ecology Notes, 4, 535-538. Trophic relationships in the Rhine food web during invasion and after establishment of the Ponto-Caspian invader Dikerogammarus villosus. Hydrobiologia, 565, 39-58. 
854

855

856

857

858

859

860

861

862

863

864

865

866

867

868

869

870

871

872

873

874

875

876

877

878

879
Von Holle B. \& Simberloff D. (2005) Ecological resistance to biological invasion overwhelmed by propagule pressure. Ecology, 86, 3212-3218. Wattier R., Engel C.R., Saumitou-Laprade P. \& Valero M (1998) Short allele dominance as a source of heterozygote deficiency at microsatellite loci: experimental evidence at the dinucleotide locus Gv1CT in Gracilaria gracilis (Rhodophyta). Molecular Ecology, 7, 1569-1573.

Wattier R.A., Beguet J., Gaillard M., Muller J.C., Bollache L. \& Perrot-Minnot M.J. (2006) Molecular markers for systematic identification and population genetics of the invasive Ponto-Caspian freshwater gammarid Dikerogammarus villosus (Crustacea, Amphipoda). Molecular Ecology Notes, 6, 487-489.

Wattier R.A., Haine E.R., Beguet J., Martin G., Bollache L., Musko I.B., Platvoet D. \& Rigaud T. (2007) No genetic bottleneck or associated microparasite loss in invasive populations of a freshwater amphipod. Oikos, 116, 1941-1953.

Weir B.S. \& Cockerham C.C. (1984) Estimating F-Statistics for the analysis of populationstructure. Evolution, 38, 1358-1370.

Wijnhoven S., Van Riel M.C. \& Van Der Velde G. (2003) Exotic and indigenous freshwater gammarid species: physiological tolerance to water temperature in relation to ionic content of the water. Aquatic Ecology, 37, 151-158.

Zhan A.B., Perepelizin P.V., Ghabooli S., Paolucci E., Sylvester F., Sardina P., Cristescu M.E. \& Macisaac H.J. (2012) Scale-dependent post-establishment spread and genetic diversity in an invading mollusc in South America. Diversity and Distributions, 18, 1042-1055.

Zhu Y., Chen H., Fan J., Wang Y., Li Y., Chen J., Fan J., Yang S., Hu L., Leung H., Mew T.W., Teng P.S., Wang Z. \& Mundt C.C. (2000) Genetic diversity and disease control in rice. Nature, 406, 718-722.

Table 1. Sampling and diversity of $D$. villosus in twelve Alpine Lakes. Acro. $=$ Acronym. Lat. $=$ Latitude. Long. $=$ Longitude. Alt. $=$ Altitude. $\mathrm{Nb}$. Boats $=$ Number of boats that could be scored on an aerial/satellite picture. Dates $=$ year of first record $/$ year of sampling. Msat $=$ microsatellites $(7$ loci). $\mathrm{mtDNA}=$ mitochondrial DNA $(2$ targets COI and $16 \mathrm{~S}) . \mathrm{N}=$ number of individual analysed. $\mathrm{Na}=$ total number of alleles or haplotypes. $\mathrm{H}_{\mathrm{E}}$ average expected heterozygosity. $A_{\mathrm{r}}=$ average allelic richness estimated with correction for sample size through rarefaction. Bottleneck $=$ results for the Wilcoxon rank test computed in BOTTLENECK under IAM, TPM and SMM microsatellite mutation models. Significant deviation from mutation/drift equilibrium $(P \leq 0.05)$ and deviation after the application of false discovery rate procedure $(\mathrm{FDR}=0.016)$ are in bold (Benjamini and Yekutieli 2001). 


\begin{tabular}{|c|c|c|c|c|c|c|c|c|c|c|c|c|c|c|c|c|c|}
\hline \multirow[t]{2}{*}{ Name } & \multirow[t]{2}{*}{ Acro. } & \multirow[t]{2}{*}{ Lat } & \multirow[t]{2}{*}{ Long } & \multirow[t]{2}{*}{ Riv. Bas. } & \multirow[t]{2}{*}{ Alt (m) } & \multirow{2}{*}{$\begin{array}{l}\text { Surface } \\
\left(\mathrm{km}^{2}\right)\end{array}$} & \multirow{2}{*}{$\begin{array}{l}\mathrm{Nb} . \\
\text { boats }\end{array}$} & \multirow[t]{2}{*}{ Dates } & \multicolumn{3}{|c|}{ Msat } & \multicolumn{3}{|c|}{ mtDNA } & \multicolumn{3}{|c|}{ Bottleneck } \\
\hline & & & & & & & & & $\bar{N}$ & $\mathrm{Na}$ & $\mathrm{H}_{\mathrm{E}} \quad A_{\mathrm{r}}$ & $\bar{N}$ & $\mathrm{Na}$ & $A_{\mathrm{r}}$ & $\overline{\text { IAM }}$ & TPM & SMM \\
\hline Traun & $34 \mathrm{~L}$ & 47.901 & 13.768 & Danube & 425 & 25.6 & 810 & $03 / 11^{a}$ & 32 & 17 & 0.432 .39 & 12 & 1 & 1.00 & 0.012 & 0.027 & 0.027 \\
\hline Constance & $35 \mathrm{~L}$ & 47.748 & 9.137 & Rhine & 395 & 536.0 & 16744 & $03 / 07^{\mathrm{b}}$ & 32 & 25 & 0.533 .43 & 6 & 2 & 1.00 & 0.004 & 0.012 & 0.020 \\
\hline Garda & $36 \mathrm{~L}$ & 45.874 & 10.867 & Po & 66 & 370.0 & 5234 & $03 / 11^{c}$ & 32 & 26 & 0.543 .50 & 12 & 1 & 1.00 & 0.008 & 0.055 & 0.234 \\
\hline Iseo & $37 \mathrm{~L}$ & 45.666 & 10.063 & Po & 200 & 61.8 & 1467 & $11 / 11^{\mathrm{d}}$ & 32 & 23 & 0.493 .12 & 12 & 1 & 1.00 & 0.016 & 0.055 & 0.055 \\
\hline Neuchâtel & $38 \mathrm{~L}$ & 46.924 & 6.953 & Rhine $^{*}$ & 440 & 218.3 & 7360 & $03 / 11^{\mathrm{e}}$ & 31 & 23 & 0.503 .12 & 12 & 2 & 2.00 & 0.008 & 0.016 & 0.039 \\
\hline Murten & $39 \mathrm{~L}$ & 46.924 & 7.037 & Rhine $^{*}$ & 450 & 22.8 & 1535 & $06 / 11^{\dagger}$ & 32 & 22 & 0.563 .09 & 11 & 2 & 2.00 & 0.008 & 0.020 & 0.027 \\
\hline Bienne & $40 \mathrm{~L}$ & 47.107 & 7.218 & Rhine $^{*}$ & 440 & 39.3 & 2749 & $05 / 11^{e}$ & 32 & 24 & 0.553 .34 & 12 & 2 & 1.95 & 0.008 & 0.008 & 0.016 \\
\hline Zug & $41 \mathrm{~L}$ & 47.180 & 8.467 & Rhine & 420 & 38.3 & 723 & $10 / 11^{g}$ & 32 & 23 & 0.503 .06 & 11 & 2 & 2.00 & 0.008 & 0.023 & 0.039 \\
\hline Zurich & $42 \mathrm{~L}$ & 47.251 & 8.627 & Rhine & 420 & 88.7 & 7506 & $06 / 11^{n}$ & 32 & 21 & 0.472 .93 & 10 & 2 & 1.99 & 0.008 & 0.016 & 0.016 \\
\hline Greifen & $43 \mathrm{~L}$ & 47.360 & 8.654 & Rhine & 425 & 8.5 & 557 & $08 / 11^{\prime}$ & 32 & 21 & 0.492 .87 & 12 & 2 & 1.99 & 0.012 & 0.148 & 0.148 \\
\hline Geneva & $44 \mathrm{~L}$ & 46.366 & 6.303 & Rhone & 372 & 582.4 & 14996 & $02 / 02^{J}$ & 32 & 17 & 0.352 .42 & 12 & 3 & 2.52 & 0.055 & 0.578 & 0.578 \\
\hline Bourget & $45 \mathrm{~L}$ & 45.800 & 5.845 & Rhone & 238 & 44.5 & 2738 & $07 / 07^{k}$ & 32 & 17 & 0.332 .35 & 6 & 2 & 2.00 & 0.047 & 0.594 & 0.594 \\
\hline
\end{tabular}


* these lakes are also interconnected through small navigable canals. a = (Holdich \& Pöckl, 2007); $\mathrm{b}=($ Mürle, Becker \& Seitz, 2003); c = (Casellato et al., 2006); d = (Bącela-Spychalska et al., 2013); e = (Lods-Crozet \& Reymond, 2006); f = (Lubini et al., 2006); g = (Steinmann, 2010); $\mathrm{h}=$ (Steinmann, Mürle \& Ortlepp, 2006); i = (Steinmann, 2008); j = (Bollache, 2004); k = (Grabowski, Bącela \& Wattier, 2007b) 
Table 2 Genetic pairwise differentiation between twelve Alpine Lakes D. villosus populations estimated for microsatellite $\left(F_{\mathrm{ST}}\right.$, below diagonal) and mitochondrial DNA data $\left(\Theta_{\mathrm{ST}}\right.$, above the diagonal). See Table 1 for acronym definition.

\begin{tabular}{|c|c|c|c|c|c|c|c|c|c|c|c|c|}
\hline $\begin{array}{l}F_{\text {ST }} \mid \Theta \\
\text { St }\end{array}$ & $34 \mathrm{~L}$ & $35 \mathrm{~L}$ & $36 \mathrm{~L}$ & $37 \mathrm{~L}$ & $38 \mathrm{~L}$ & $39 \mathrm{~L}$ & $40 \mathrm{~L}$ & $41 \mathrm{~L}$ & $42 \mathrm{~L}$ & $43 \mathrm{~L}$ & $44 \mathrm{~L}$ & $45 \mathrm{~L}$ \\
\hline $34 \mathrm{~L}$ & - & $\begin{array}{l}0.000 \\
\text { ns }\end{array}$ & $\begin{array}{l}0.000 \\
\text { ns }\end{array}$ & $\begin{array}{l}0.000 \\
\mathrm{~ns}\end{array}$ & $\begin{array}{l}0.364 \\
\text { ns }\end{array}$ & $\begin{array}{l}0.613 \\
* *\end{array}$ & $\begin{array}{l}0.091 \\
\text { ns }\end{array}$ & $\begin{array}{l}0.576 \\
* *\end{array}$ & $\begin{array}{l}0.670 \\
* *\end{array}$ & $\begin{array}{l}0.590 \\
* *\end{array}$ & $\begin{array}{l}0.000 \\
\text { ns }\end{array}$ & $\begin{array}{l}0.124 \\
\text { ns }\end{array}$ \\
\hline $35 \mathrm{~L}$ & $\begin{array}{l}0.174 \\
* *\end{array}$ & - & $\begin{array}{l}0.000 \\
\text { ns }\end{array}$ & $\begin{array}{l}0.000 \\
\text { ns }\end{array}$ & $\begin{array}{l}0.260 \\
\text { ns }\end{array}$ & $\begin{array}{l}0.516 \\
\text { ns }\end{array}$ & $\begin{array}{l}0.008 \\
\text { ns }\end{array}$ & $\begin{array}{l}0.475 \\
* *\end{array}$ & $\begin{array}{l}0.574 \\
* *\end{array}$ & $\begin{array}{l}0.496 \\
* *\end{array}$ & $\begin{array}{l}- \\
0.069 \\
\text { ns }\end{array}$ & $\begin{array}{l}0.000 \\
\text { ns }\end{array}$ \\
\hline $36 \mathrm{~L}$ & $\begin{array}{l}0.129 \\
\star *\end{array}$ & $\begin{array}{l}0.037 \\
* *\end{array}$ & - & $\begin{array}{l}0.000 \\
\text { ns }\end{array}$ & $\begin{array}{l}0.364 \\
\text { ns }\end{array}$ & $\begin{array}{l}0.613 \\
* *\end{array}$ & $\begin{array}{l}0.091 \\
\text { ns }\end{array}$ & $\begin{array}{l}0.576 \\
* *\end{array}$ & $\begin{array}{l}0.670 \\
* *\end{array}$ & $\begin{array}{l}0.590 \\
* *\end{array}$ & $\begin{array}{l}0.000 \\
\text { ns }\end{array}$ & $\begin{array}{l}0.124 \\
n s\end{array}$ \\
\hline $37 \mathrm{~L}$ & $\begin{array}{l}0.176 \\
\star *\end{array}$ & $\begin{array}{l}0.057 \\
* *\end{array}$ & $\begin{array}{l}0.010 \\
\text { ns }\end{array}$ & - & $\begin{array}{l}0.364 \\
\text { ns }\end{array}$ & $\begin{array}{l}0.613 \\
* *\end{array}$ & $\begin{array}{l}0.091 \\
\text { ns }\end{array}$ & $\begin{array}{l}0.576 \\
* *\end{array}$ & $\begin{array}{l}0.670 \\
* *\end{array}$ & $\begin{array}{l}0.590 \\
* *\end{array}$ & $\begin{array}{l}0.000 \\
\text { ns }\end{array}$ & $\begin{array}{l}0.124 \\
n s\end{array}$ \\
\hline $38 \mathrm{~L}$ & $\begin{array}{l}0.153 \\
* *\end{array}$ & $\begin{array}{l}0.106 \\
* *\end{array}$ & $\begin{array}{l}0.030 \\
* *\end{array}$ & $\begin{array}{l}0.031^{*} \\
*\end{array}$ & - & $\begin{array}{l}0.006 \\
\text { ns }\end{array}$ & $\begin{array}{l}0.063 \\
\text { ns }\end{array}$ & $\begin{array}{l}0.471 \\
\text { ns }\end{array}$ & $\begin{array}{l}0.511 \\
* *\end{array}$ & $\begin{array}{l}0.488 \\
* *\end{array}$ & $\begin{array}{l}0.303 \\
\text { ns }\end{array}$ & $\begin{array}{l}0.246 \\
\mathrm{~ns}\end{array}$ \\
\hline $39 \mathrm{~L}$ & $\begin{array}{l}0.175 \\
* *\end{array}$ & $\begin{array}{l}0.120 \\
* *\end{array}$ & $\begin{array}{l}0.047 \\
\star *\end{array}$ & $\begin{array}{l}0.056^{*} \\
\text { * }\end{array}$ & $\begin{array}{l}0.023 \\
* *\end{array}$ & - & $\begin{array}{l}0.316 \\
\text { ns }\end{array}$ & $\begin{array}{l}0.584 \\
\text { ns }\end{array}$ & $\begin{array}{l}0.617 \\
* *\end{array}$ & $\begin{array}{l}0.597 \\
* *\end{array}$ & $\begin{array}{l}0.538 \\
* *\end{array}$ & $\begin{array}{l}0.483 \\
\text { ns }\end{array}$ \\
\hline $40 \mathrm{~L}$ & $\begin{array}{l}0.082 \\
* *\end{array}$ & $\begin{array}{l}0.073 \\
* *\end{array}$ & $\begin{array}{l}0.020 \\
\text { ns }\end{array}$ & $\begin{array}{l}0.042^{*} \\
*\end{array}$ & $\begin{array}{l}0.009 \\
\text { ns }\end{array}$ & $\begin{array}{l}0.029 \\
* *\end{array}$ & - & $\begin{array}{l}0.448 \\
\text { ns }\end{array}$ & $\begin{array}{l}0.508 \\
* *\end{array}$ & $\begin{array}{l}0.466 \\
* *\end{array}$ & $\begin{array}{l}0.061 \\
\text { ns }\end{array}$ & $\begin{array}{l}0.034 \\
\text { ns }\end{array}$ \\
\hline $41 \mathrm{~L}$ & $\begin{array}{l}0.043 \\
* *\end{array}$ & $\begin{array}{l}0.094 \\
* *\end{array}$ & $\begin{array}{l}0.060 \\
* *\end{array}$ & $\begin{array}{l}0.108^{*} \\
*\end{array}$ & $\begin{array}{l}0.095 \\
* *\end{array}$ & $\begin{array}{l}0.122 \\
* *\end{array}$ & $\begin{array}{l}0.036 \\
* *\end{array}$ & - & $\begin{array}{l}- \\
0.090 \\
\text { ns }\end{array}$ & $\begin{array}{l}0.312 \\
\text { ns }\end{array}$ & $\begin{array}{l}0.489 \\
* *\end{array}$ & $\begin{array}{l}0.438 \\
* *\end{array}$ \\
\hline $42 \mathrm{~L}$ & $\begin{array}{l}0.054 \\
* *\end{array}$ & $\begin{array}{l}0.130 \\
* *\end{array}$ & $\begin{array}{l}0.067 \\
* *\end{array}$ & $\begin{array}{l}0.123^{*} \\
\text { * }\end{array}$ & $\begin{array}{l}0.100 \\
* *\end{array}$ & $\begin{array}{l}0.144 \\
\star *\end{array}$ & $\begin{array}{l}0.052 \\
* *\end{array}$ & $\begin{array}{l}0.007 \\
\text { ns }\end{array}$ & - & $\begin{array}{l}0.410 \\
\text { ns }\end{array}$ & $\begin{array}{l}0.562 \\
* *\end{array}$ & $\begin{array}{l}0.522 \\
* *\end{array}$ \\
\hline $43 \mathrm{~L}$ & $\begin{array}{l}0.045 \\
* *\end{array}$ & $\begin{array}{l}0.138 \\
* *\end{array}$ & $\begin{array}{l}0.088 \\
* *\end{array}$ & $\begin{array}{l}0.147^{*} \\
\text { * }\end{array}$ & $\begin{array}{l}0.145 \\
* *\end{array}$ & $\begin{array}{l}0.152 \\
\star *\end{array}$ & $\begin{array}{l}0.074 \\
* *\end{array}$ & $\begin{array}{l}0.021 \\
\text { ns }\end{array}$ & $\begin{array}{l}0.020 \\
\text { ns }\end{array}$ & - & $\begin{array}{l}0.506 \\
* *\end{array}$ & $\begin{array}{l}0.460 \\
* *\end{array}$ \\
\hline $44 \mathrm{~L}$ & $\begin{array}{l}0.198 \\
* *\end{array}$ & $\begin{array}{l}0.092 \\
* *\end{array}$ & $\begin{array}{l}0.077 \\
* *\end{array}$ & $\begin{array}{l}0.120^{*} \\
*\end{array}$ & $\begin{array}{l}0.148 \\
* *\end{array}$ & $\begin{array}{l}0.190 \\
* *\end{array}$ & $\begin{array}{l}0.107 \\
* *\end{array}$ & $\begin{array}{l}0.101 \\
* *\end{array}$ & $\begin{array}{l}0.129 \\
* \star\end{array}$ & $\begin{array}{l}0.144 \\
* *\end{array}$ & - & $\begin{array}{l}0.091 \\
\text { ns }\end{array}$ \\
\hline $45 \mathrm{~L}$ & $\begin{array}{l}0.229 \\
\star *\end{array}$ & $\begin{array}{l}0.126 \\
* *\end{array}$ & $\begin{array}{l}0.089 \\
\star *\end{array}$ & $\begin{array}{l}0.133^{*} \\
*\end{array}$ & $\begin{array}{l}0.160 \\
* *\end{array}$ & $\begin{array}{l}0.187 \\
\star *\end{array}$ & $\begin{array}{l}0.127 \\
\star *\end{array}$ & $\begin{array}{l}0.130 \\
* *\end{array}$ & $\begin{array}{l}0.146 \\
\star *\end{array}$ & $\begin{array}{l}0.155 \\
* *\end{array}$ & $\begin{array}{l}- \\
0.003 \\
\text { ns }\end{array}$ & - \\
\hline
\end{tabular}

ns, not significant; bold $* * P \leq 0.01$ 


\section{Supplementary Table}

Supplementary Table 1. GenBank accession numbers of COI and 16S haplotypes

Supplementary Table 2. Migration rates between source and receiver lakes within two groups of lakes.

Supplementary Table 3. Comparisons of allele distributions between control populations (populations on the Western Route of invasion), and Alpine lake populations

\section{Figure Captions:}

Fig. 1. (a) The dynamics of Dikerogammarus villosus invasion in main water bodies of Europe: dates of first records along the invasion highways (e.g. the Western route $=\mathrm{WR}$ and the Eastern route $=E R$ ) are indicated, shadowed area - the Alpine Arch. (b) Small black dots represent the positions of the 48 lakes sampled during the field survey along the Alpine Arch, where D. villosus was absent (for all lake names see Bącela-Spychalska et al 2013a). Big black dots indicating lakes with $D$. villosus are supplemented by locality acronyms (details in Table 1) and date of first record of D. villosus. Main rivers and their affluent are indicated by colours: Rhone - yellow, Rhine - red, Po - blue, Danube - green.

Fig. 2. Haplotype distribution of D. villosus in continental Europe. (a) Native area, western route and eastern route of invasion in continental lowlands (from Rewicz et al. (2015a)). (b) Alpine Lakes region. Black dots represent lakes with D. villosus. (c) Minimum spanning network based on data from Rewicz et al. (2015a) and from present study. * - new haplotypes associated with the present study.

Fig. 3. Bayesian clustering of D. villosus based on six microsatellite loci from: (a) 36 populations collected in Alpine Lakes (L), native (N) area, western route (WR) and eastern route (ER) of invasion for $K=3$. Acronyms refer to sites as detailed in Rewicz et al. (2015a) and in Table 1. (b) Bayesian clustering of D. villosus based on seven microsatellite loci from12 populations from the Alpine Lakes with $K=3$. Each individual is represented by a thin vertical line, with proportional assignment to different clusters indicated by colours. Black vertical lines separate sampling sites, identified below the plot. 
Fig. 4. Comparison of (a) allelic richness and (b) expected heterozygosity between eleven populations from the western route of invasion and the populations from the Alpine Lakes. The boxes represent 25 th- 75 th percentiles, upper and lower whiskers indicate minimum and maximum values. Square inside each box indicates median value. Non-parametric Wilcoxon rank test $\left(A_{\mathrm{r}}: \mathrm{Z}=2.93 \mathrm{p}=0.003 ; \mathrm{H}_{\mathrm{E}}: \mathrm{Z}=2.85, \mathrm{p}=0,004\right)$

Fig. 5. Allele frequency distribution in populations of D. villosus from the 12 Alpine Lakes (black bars), compared with population WR19 (grey bars - same population in each diagram) that has not experienced a bottleneck and. Bottlenecks are expected to shift the mode by reducing the number of rare alleles. The population of WR19 is representative of other populations surrounding the Alpine Arch (not showed). It was chosen to illustrate the allele distribution in populations outside the Alps as it is the geographically closest population to the Alpine Lakes. 
Illustrations

Fig. 1

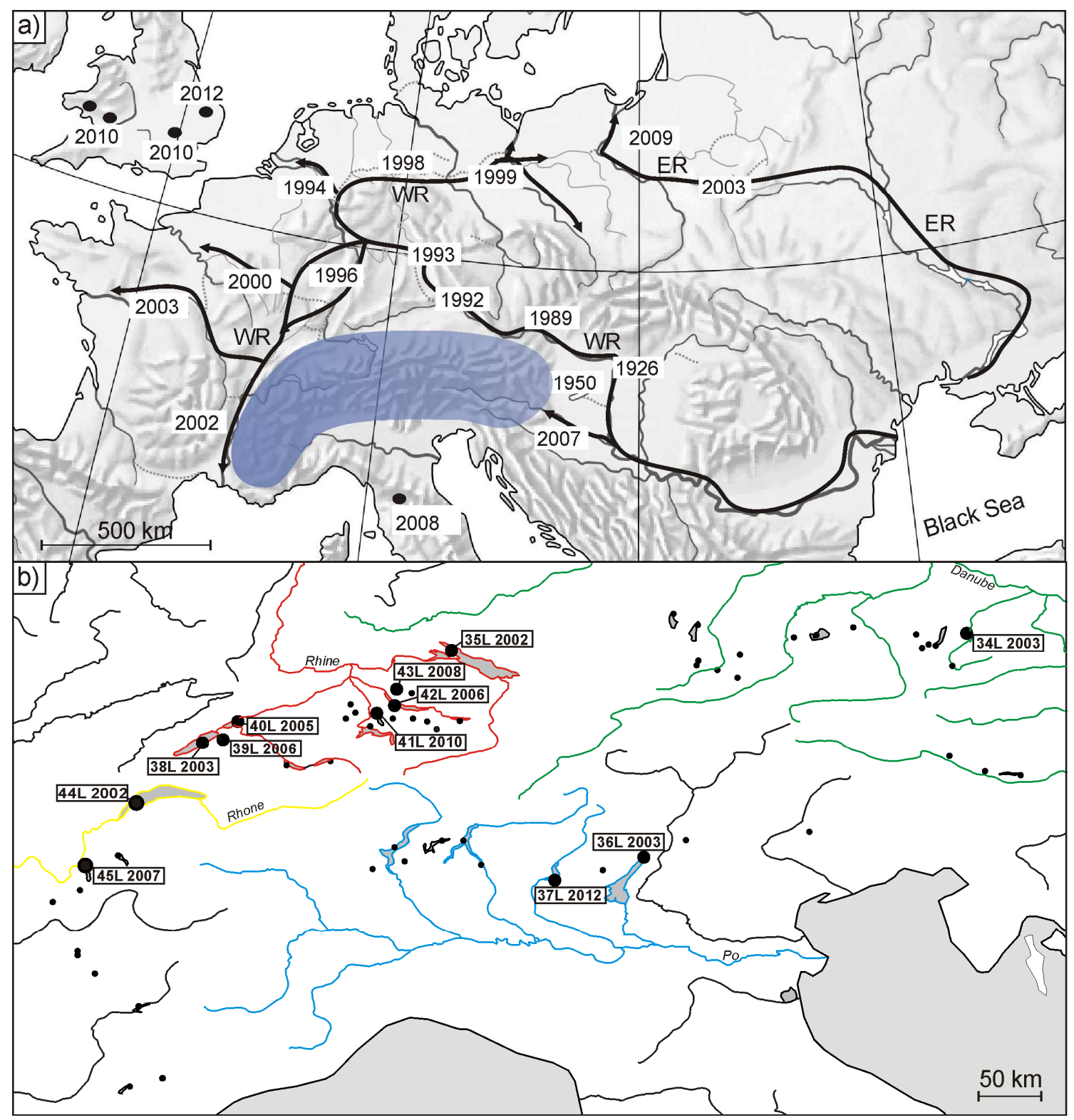


Fig. 2
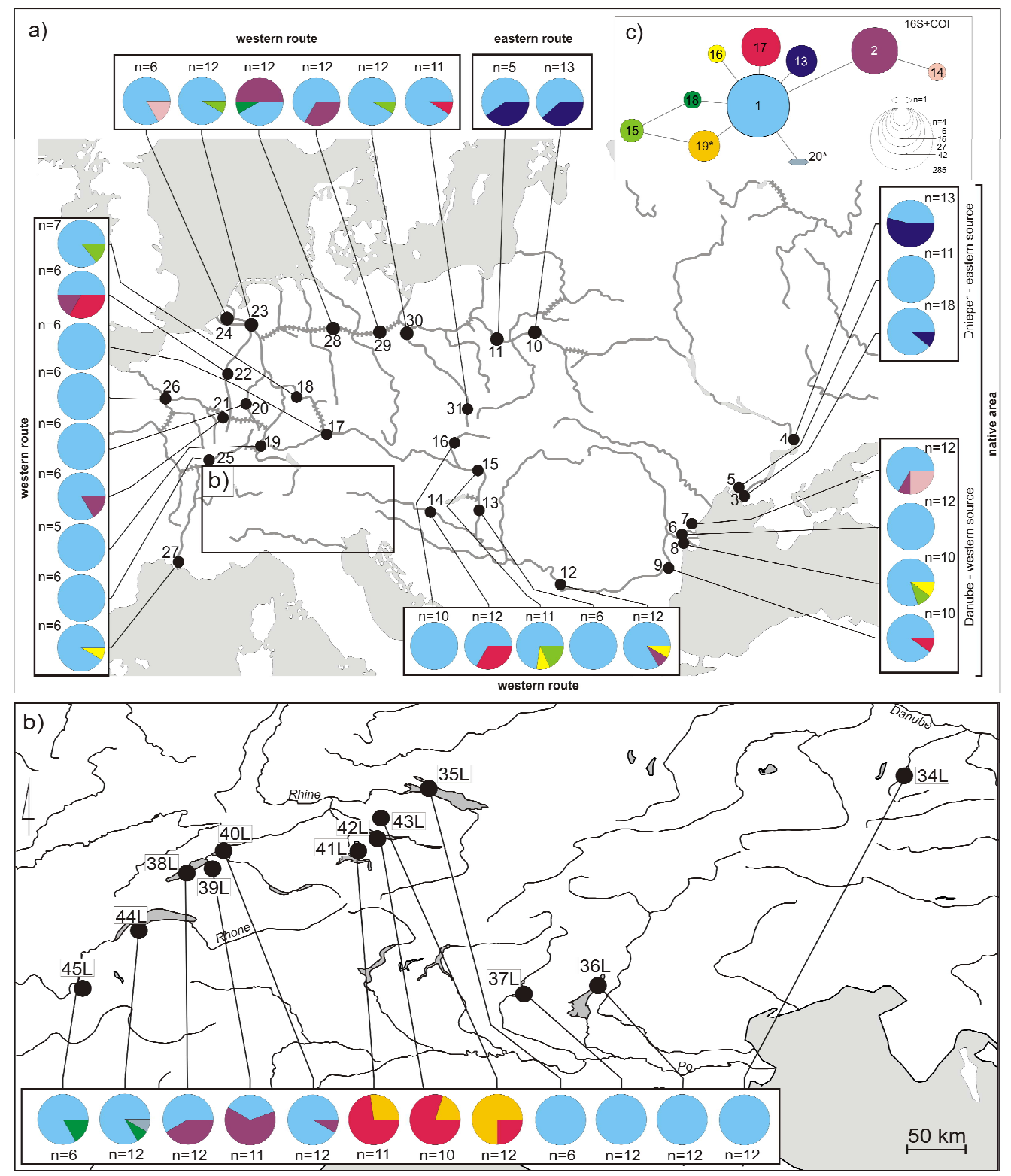
Fig. 3
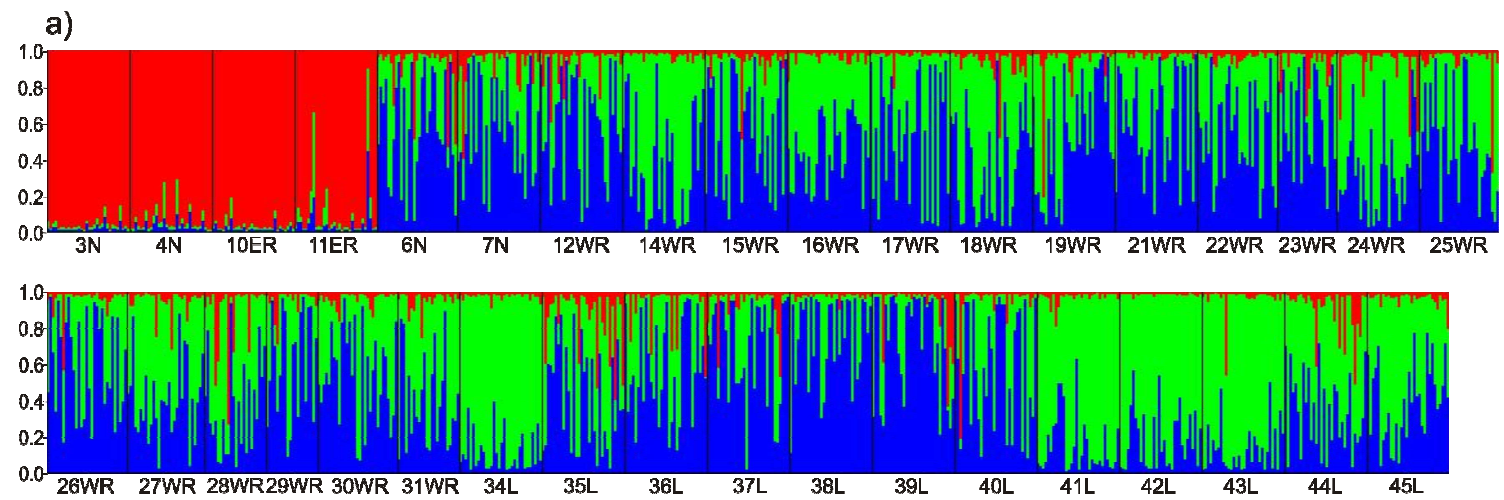

b)

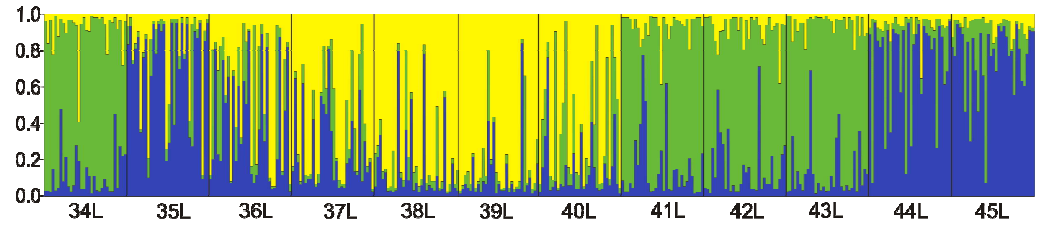

Fig. 4

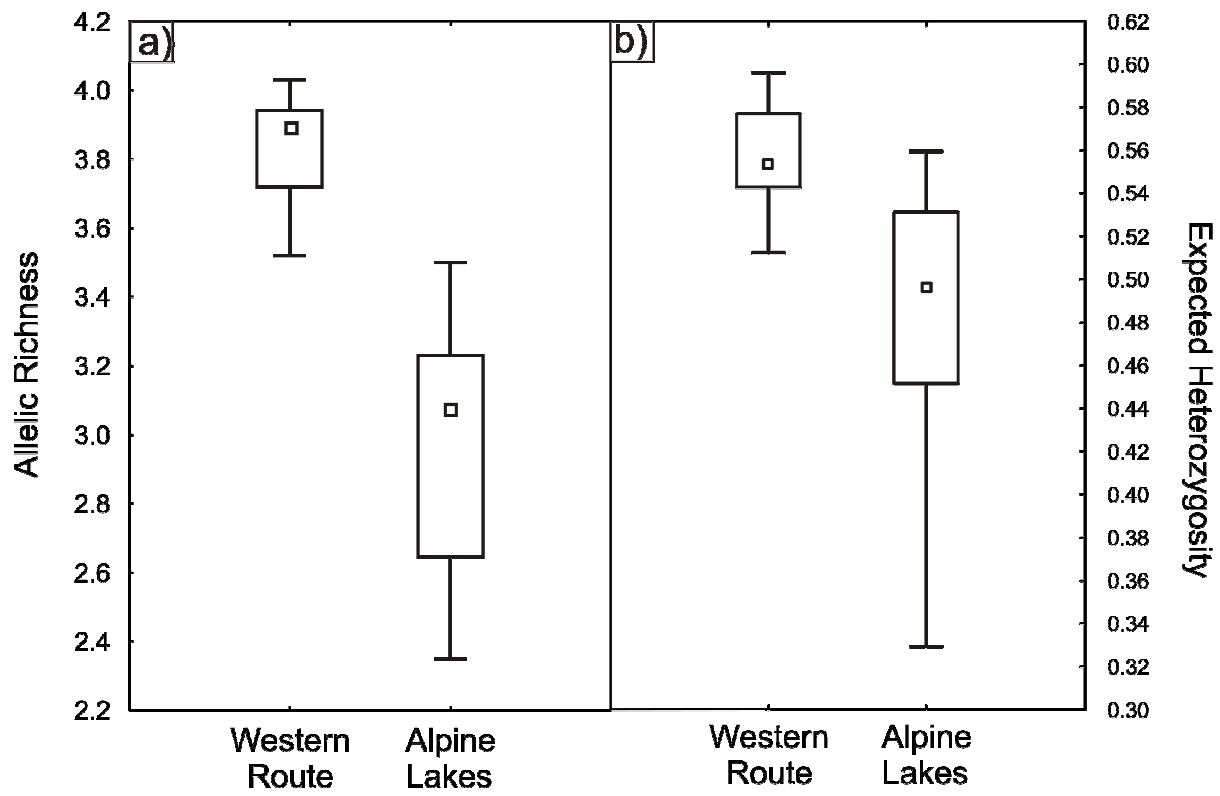

48

49

50

51

52

53

54

55

56 
Freshwater Biology

Page 34 of 37

Fig. 5

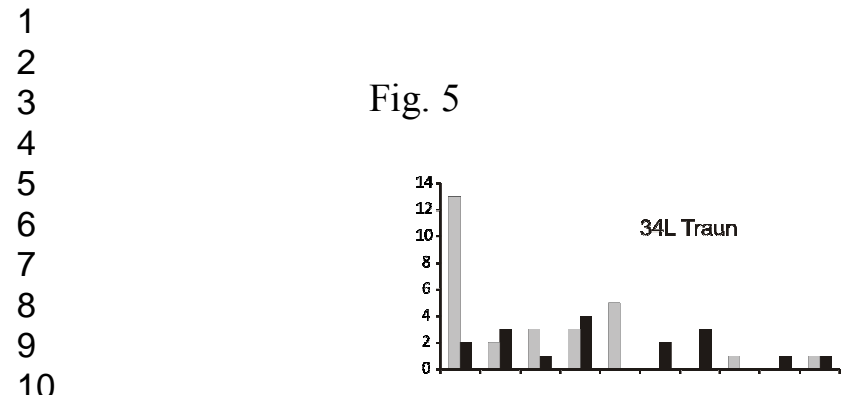

11

12

13

14

15

16

17

18

19

20

21

22

23

24

25

26

27

28

29

30

31

32

33

34

35

36

37

38

39

40

41

42

43

44

45

46

47

48

49

50

51

52

53

54

55

56

57

58

59

60
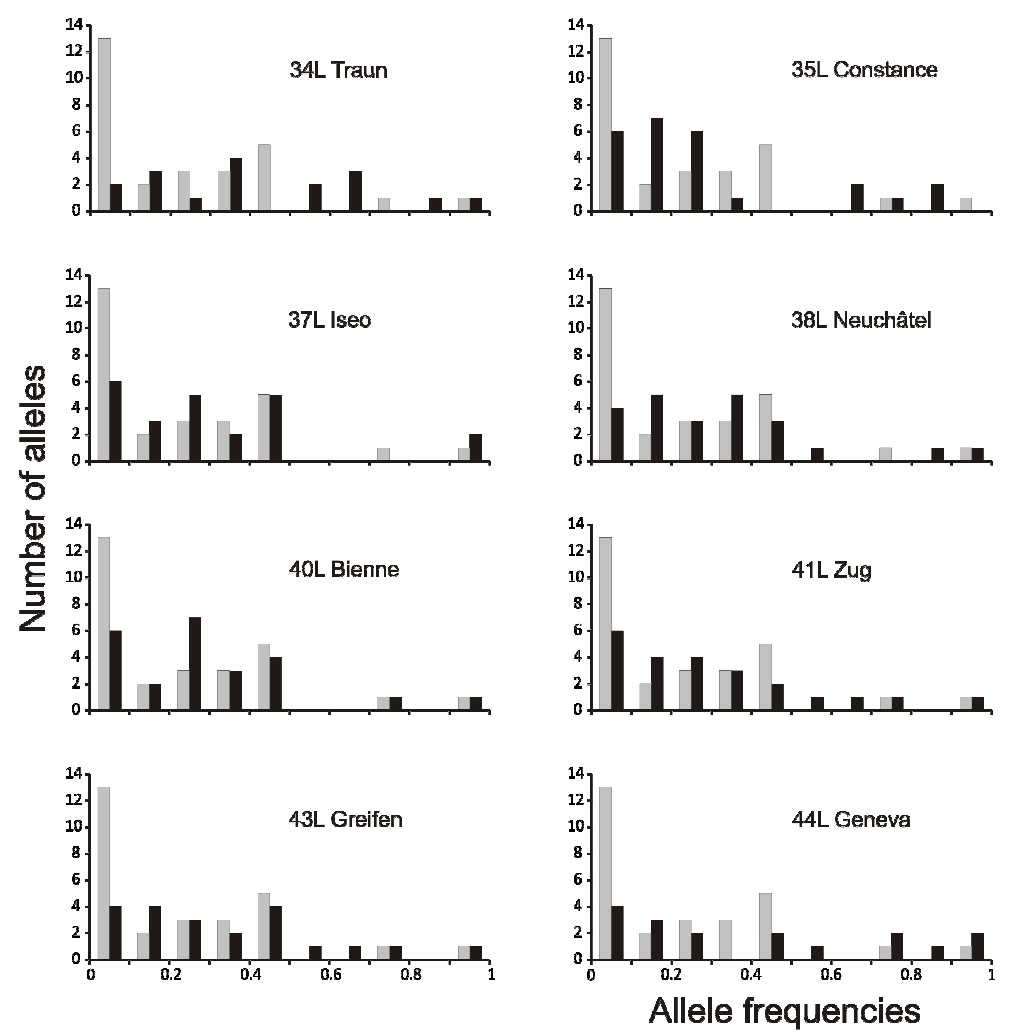
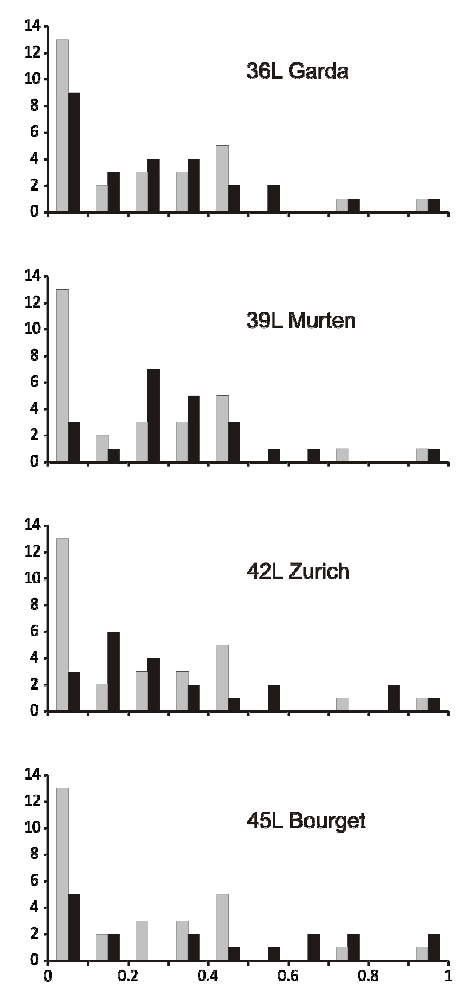

34 
Table S1 Assignment of the individuals to the COI and 16S haplotypes as well as concatenated ones $(16 \mathrm{~S}+\mathrm{COI})$ with GeneBank accession numbers. Code for the individual consist of the lake number as in Figure 1 and number of the individual.

\begin{tabular}{|c|c|c|c|}
\hline $16 \mathrm{~S}+\mathrm{COI}$ & $16 \mathrm{~S}$ & $\mathrm{COI}$ & Individuals \\
\hline hap 1 & hap 1 KM208876 & hap 13 KM208874 & $\begin{array}{l}\text { L34/1; L34/10; L34/11; L34/12; } \\
\text { L34/15; L34/16; L34/17; L34/19; } \\
\text { L34/24; L34/6; L34/8; L34/9; } \\
\text { L35/10; L35/5; L35/6; L35/7; } \\
\text { L35/8; L35/9; L36/1; L36/10; } \\
\text { L36/14; L36/15; L36/16; L36/19; } \\
\text { L36/2; L36/20; L36/3; L36/4; } \\
\text { L36/8; L36/9; L37/10; L37/11; } \\
\text { L37/12; L37/14; L37/15; L37/3; } \\
\text { L37/4; L37/5; L37/6; L37/7; } \\
\text { L37/8; L37/9; L38/14; L38/15; } \\
\text { L38/16; L38/17; L38/5; L38/6; } \\
\text { L38/7; L39/10; L39/13; L39/5; } \\
\text { L39/8; L40/10; L40/11; L40/12; } \\
\text { L40/13; L40/4; L40/5; L40/6; } \\
\text { L40/7; L40/8; L40/9; L44/11; } \\
\text { L44/12; L44/16; L44/18; L44/19; } \\
\text { L44/2; L44/3; L44/4; L44/7; } \\
\text { L44/9; L45/1; L45/2; L45/3; } \\
\text { L45/5; L45/6 }\end{array}$ \\
\hline hap 2 & hap 1 KM208876 & hap 2 KM208863 & $\begin{array}{l}\text { L38/10; L38/11; L38/12; L38/2; } \\
\text { L38/9; L39/1; L39/11; L39/12; } \\
\text { L39/14; L39/3; L39/6; L39/9; } \\
\text { L40/1; L40/2 }\end{array}$ \\
\hline hap 17 & hap 1 KM208876 & hap 14 KM208875 & $\begin{array}{l}\text { L41/12; L41/2; L41/3; L41/4; } \\
\text { L41/5; L41/6; L41/7; L41/8; } \\
\text { L42/10; L42/12; L42/17; L42/2; } \\
\text { L42/3; L42/7; L42/8; L42/9; } \\
\text { L43/1; L43/11; L43/5 }\end{array}$ \\
\hline hap 18 & hap 1 KM208876 & hap 13 KM208874 & L44/20; L45/9 \\
\hline hap 19 & hap 4 KM208879 & hap 1 KM208862 & $\begin{array}{l}\text { L41/10; L41/11; L41/13; L42/11; } \\
\text { L42/5; L43/10; L43/12; L43/13; } \\
\text { L43/3; L43/4; L43/6; L43/7; } \\
\text { L43/8; L43/9 }\end{array}$ \\
\hline hap 20 & hap 1 KM208876 & hap 15 KP814111 & $\mathrm{L} 44 / 13$ \\
\hline
\end{tabular}


Table S2. Migration rates between Source and Receiver lakes within two groups of lakes. Median values for two runs ( 1 and 2$)$ are given for mutation-scaled migration rate $M(M=$ $\mathrm{m} / \mu$, where $\mathrm{m}$ is the immigration rate per generation and $\mu$ is the mutation rate) estimated using Bayesian inference in program MIGRATE-N.

\begin{tabular}{lllllll}
\hline Group & Source & & Receiver & & run 1 & run 2 \\
\hline \multirow{2}{*}{ Neuchâtel -group } & Murten & 39L & Neuchâtel & 38L & 21.1 & 17.5 \\
& Bienne & 40L & Neuchâtel & 38L & 16.1 & 19.5 \\
& Neuchâtel & 38L & Murten & 39L & 14.5 & 12.7 \\
& Bienne & 40L & Murten & 39L & 21.1 & 21.1 \\
& Neuchâtel & 38L & Bienne & 40L & 23.9 & 28.7 \\
& Murten & 39L & Bienne & 40L & 20.5 & 23.7 \\
& Zurich & 42L & Zug & 41L & 13.9 & 30.7 \\
& Greifen & 43L & Zug & 41L & 17.9 & 21.9 \\
& Zug & 41L & Zurich & 42L & 20.9 & 11.5 \\
& Greifen & 43L & Zurich & 42L & 20.1 & 19.7 \\
& Zug & 41L & Greifen & 43L & 13.9 & 15.5 \\
& Zurich & 42L & Greifen & 43L & 18.1 & 18.7 \\
\hline
\end{tabular}


Table S3: Comparisons of allele distributions between control populations (populations on the Western Route of invasion, the closest from the Alpine arc), and Alpine Lake populations, using non parametric test of Dunn with Control for Joint Ranks. Only significant comparisons are provided.

\begin{tabular}{|c|c|c|c|}
\hline Control population & Lake population & $\mathbf{Z}$ & P-value \\
\hline WR15 & Geneva & 4.82 & $<0.0001$ \\
\hline WR15 & Traun & 4.58 & $<0.0001$ \\
\hline WR15 & Bourget & 4.47 & $<0.0001$ \\
\hline WR15 & Greifen & 3.98 & 0.0008 \\
\hline WR15 & Zurich & -3.29 & 0.01 \\
\hline WR15 & Zug & -3.07 & 0.02 \\
\hline WR15 & Neuchatel & 2.85 & 0.05 \\
\hline WR17 & Geneva & 3.94 & 0.001 \\
\hline WR17 & Traun & 3.71 & 0.002 \\
\hline WR17 & Bourget & 3.56 & 0.004 \\
\hline WR17 & Greifen & 3.04 & 0.03 \\
\hline WR19 & Geneva & 4.35 & 0.0002 \\
\hline WR19 & Traun & 4.11 & 0.0005 \\
\hline WR19 & Bourget & 3.97 & 0.0008 \\
\hline WR19 & Greifen & 3.50 & 0.005 \\
\hline WR27 & Geneva & 3.67 & 0.003 \\
\hline WR27 & Traun & 3.45 & 0.007 \\
\hline WR27 & Bourget & 3.23 & 0.01 \\
\hline
\end{tabular}

